Review

\title{
Cardiomyopathies and Related Changes in Contractility of Human Heart Muscle
}

\author{
Petr G. Vikhorev ${ }^{1, *(D)}$ and Natalia N. Vikhoreva ${ }^{2}$ \\ 1 National Heart and Lung Institute, Imperial College London, London W12 0NN, UK \\ 2 Heart Science Centre, Magdi Yacoub Institute, Harefield Hospital, London UB9 6JH, UK; \\ nataliav@myi.org.uk \\ * Correspondence: p.vikhorev@imperial.ac.uk
}

Received: 8 July 2018; Accepted: 27 July 2018; Published: 31 July 2018

\begin{abstract}
About half of hypertrophic and dilated cardiomyopathies cases have been recognized as genetic diseases with mutations in sarcomeric proteins. The sarcomeric proteins are involved in cardiomyocyte contractility and its regulation, and play a structural role. Mutations in non-sarcomeric proteins may induce changes in cell signaling pathways that modify contractile response of heart muscle. These facts strongly suggest that contractile dysfunction plays a central role in initiation and progression of cardiomyopathies. In fact, abnormalities in contractile mechanics of myofibrils have been discovered. However, it has not been revealed how these mutations increase risk for cardiomyopathy and cause the disease. Much research has been done and still much is being done to understand how the mechanism works. Here, we review the facts of cardiac myofilament contractility in patients with cardiomyopathy and heart failure.
\end{abstract}

Keywords: human heart muscle contractility; dilated cardiomyopathy; hypertrophic cardiomyopathy; troponin phosphorylation; cardiomyopathy mutations; $\mathrm{Ca}^{2+}$-sensitivity; length dependent activation

\section{Introduction}

The main function of the heart is pumping the blood around the body according to the organism's physiological requirements [1]. Heart contraction is initiated by the action potential propagated from sinoatrial node pacemaker cells. Membrane depolarization opens voltage-gated L-type $\mathrm{Ca}^{2+}$ channels in the cytoplasmic membrane. The initial influx of $\mathrm{Ca}^{2+}$ further stimulates efflux of $\mathrm{Ca}^{2+}$ from sarcoplasmic reticulum via ryanodine receptor type-2 channels [2,3]. $\mathrm{Ca}^{2+}$ binds to troponin $\mathrm{C}$ of the troponin complex, which is composed of three subunits: troponin C, I, and T. Troponin is attached to tropomyosin, which lies along the actin filament, and regulates its position depending on the $\mathrm{Ca}^{2+}$ concentration [4,5]. Tropomyosin blocks myosin binding sites on actin at low $\mathrm{Ca}^{2+}$ concentration. When $\left[\mathrm{Ca}^{2+}\right]$ increases, tropomyosin releases the sites and promotes interaction of myosin with actin. Uptake of $\mathrm{Ca}^{2+}$ from cytoplasm by sarcoplasmic/endoplasmic reticulum $\mathrm{Ca}^{2+}$-ATPase $\mathrm{Na}^{+} / \mathrm{Ca}^{2+}$ exchanger stimulates relaxation [2,3]. It is widely accepted that myofilament $\mathrm{Ca}^{2+}$ sensitivity is regulated via phosphorylation of troponin I (TnI) at Ser 23 and 24 [6-8]. The phosphorylation of other proteins, such as myosin binding protein $\mathrm{C}$ [9] and regulatory light chain of myosin, also can modulate $\mathrm{Ca}^{2+}$ sensitivity [10-12] but to a lesser degree.

Cardiomyopathy is a disease of the heart muscle leading to cardiac dysfunction with characteristic pathological remodeling and eventually to heart failure. Besides cardiomyopathies, heart failure can be caused by other conditions, particularly by coronary artery disease and hypertension which are the leading causes of cardiac death [13]. There are several different types of cardiomyopathies: hypertrophic cardiomyopathy (HCM), dilated cardiomyopathy (DCM), restrictive 
(RC), and arrhythmogenic right ventricular (ARVC) [14-18]. Hypertrophic cardiomyopathy, DCM, and ARVC have been recognized as genetic diseases [19,20].

Dilated cardiomyopathy and HCM are the most common types of cardiomyopathies and they have been intensively studied. Hypertrophic cardiomyopathy affects one in 500 of the population and DCM affects one in 250-500 [17]. They both have been implicated with a high risk of sudden cardiac death, where DCM accounts for $30-40 \%$ of heart failure $[13,19,21]$. Dilated cardiomyopathy and HCM decrease stroke volume and cardiac output but in different ways [22]. Hypertrophic cardiomyopathy is characterized by a pathologically hypertrophied (wall thickness $>15 \mathrm{~mm}$ ) left ventricle and septum and without left ventricular cavity dilatation. This leads to a decrease of the intraventricular dimension and blood flow obstruction resulting in diastolic dysfunction. In about $10 \%$ of patients, HCM may progress further to a dilated phenotype [23]. The morphologic macroscopic changes do not always become apparent. Myocyte disarray exceeding $5-10 \%$ is the recognized trademark for HCM diagnosis [24]. On the contrary, the left ventricle of a DCM heart is dilated and the walls become thinner [25]. The heart cannot contract properly and left ventricular ejection fraction is reduced ( $<45 \%$; systolic dysfunction). Hypertrophic cardiomyopathy and DCM can show morphological variations [23,25-27] and often can be misdiagnosed.

Dilated cardiomyopathy can be initiated by different conditions: autoimmune diseases (diabetes, thyroid disease), infections, and toxins (alcohol, chemotherapy), high blood pressure, heart attack or coronary artery disease [28,29]. It should be noted that the case of dilated cardiomyopathy which develops after a myocardial infarction or ischemia is often classified as a separate disease entity: ischemic cardiomyopathy (ICM) [25,28-31]. The environmental cases can also have genetic predisposition [32,33]. If known cause is not identified, DCM is called idiopathic DCM. Idiopathic DCM accounts for $50 \%$ of all cases $[25,34,35]$ and its prevalence in children is higher $(66 \%)$ [36]. Family screening shows that $30-50 \%$ of all idiopathic DCM cases are familial [19]. Whole genome sequencing analysis revealed that mutations were the main underlying cause of the disease in about $50 \%$ of patients diagnosed with idiopathic DCM. Dilated cardiomyopathy is a polygenetic disease with mutations found in sarcomeric, structural, and other protein genes; mutations in 57 genes have been linked to DCM [20]. Where mutations in the titin gene (TTN) are the most frequent (11.6-21.4\%) [37-39] and account for $\sim 25-27.6 \%$ of familial $[37,40]$ and $11.6-18 \%$ of sporadic $[37,38]$ genetic cases. The genes of sarcomeric proteins more frequently identified as genetic cause are $M Y H 7$ ( $\beta$-cardiac myosin heavy chain), TPM1 (tropomyosin alpha-1 chain), and the genes of cardiac troponins TNNT2 (troponin T), TNNI3 (troponin I), and TNNC1 (troponin C).

In the case of HCM, pathogenic mutations, which were found in $37.9-63.2 \%$ cases [41-47], are located mostly in the genes of nine sarcomeric proteins: $M Y H 7, M Y B P C 3$ (cardiac myosin binding protein C), TNNT2, TNNI3, TNNC1, TPM1, ACTC (cardiac actin), MYL2 (ventricular myosin light chain 2, LC2), and MYL3 (myosin light chain 3) [42,43,48-50]. Where $74-85.1 \%$ of all mutations are in the genes of MYBPC3 (36.2-54.8\%) and MYH7 (25-48.9\%) [42-47].

In our review we summarize the changes of contractile property of human cardiac muscle associated with DCM and HCM.

\section{Approaches and Parameters to Estimate Contractility}

It is recognized that myofibril contractile dysfunction plays a central role in initiation and progression of cardiac disease. However, how pathogenic mutations increase risk of cardiomyopathies or cause the diseases is unclear. The common explanation is that mutations in the contractile and regulatory proteins of sarcomere disturb muscle contraction. Mutations in titin change viscoelasticity properties, and mutations in other non-contractile proteins may induce defects in cell signaling pathways that modify cardiac response. But it seems that the mechanism is complex and there is no model that explains the mechanism of disease.

Numerous studies have been done using patient heart samples as well as animal models of cardiomyopathies and chimeric protein constructs with recombinant proteins from different sources to 
understand the diseases. However, in this review we would like to summarize the experimental data obtained only from human heart muscle samples. Skinned muscle strips, isolated cardiomyocytes, and myofibrils obtained from frozen patient hearts [51] were used to study heart contractility [52-54]. As DCM and HCM affect the left ventricle more, most of the research has been done on left ventricular and septum samples, and not much is known about whether there are significant abnormalities in the contractility of the atriums and right ventricle.

The fundamental parameters used to describe muscle contractility are: the force generating capacity $\left(F_{\max }\right)$ and $\mathrm{Ca}^{2+}$-sensitivity $\left(E C_{50}\right.$; and $n_{\mathrm{H}}$ is a parameter characterizing the steepness of the sigmoidal curve). Furthermore, the fast kinetics of myofilament contractility can be measured only in a single myofibril, due to the relatively slow diffusion in samples more than a few microns thick, such as cardiomyocytes. This technique is far more advantageous in respect to the understanding of the molecular mechanisms of cardiomyopathies as it also provides us with data on myosin cross-bridge kinetics and the mechanisms of activation and relaxation in a single muscle myofibril $[53,54]$. Once $\left[\mathrm{Ca}^{2+}\right]$ reaches a certain threshold, force rapidly develops until it reaches plateau $\left(F_{\max }\right)$. The time course of force development can be fitted with a single exponential function characterized by the rate constant $k_{\mathrm{ACT}}$. The activation rate is highly dependent on the concentration of $\mathrm{Ca}^{2+}$ in activating solution.

Relaxation has two phases: slow and fast. The first phase is nearly isotonic, with a slow linear decline in tension, and it lasts about $100 \mathrm{~ms}$. The slow phase can be fit with a linear function and characterized by the rate constant $k_{\mathrm{LIN}}$, which is calculated from the slope value of the linear fit by normalizing it to the maximum tension $\left(k_{\mathrm{LIN}}=-\right.$ slope $\left./ F_{\mathrm{max}}\right)$, and the duration time $t_{\mathrm{LIN}}$. After the latent period, the slow phase translates into an exponential force decay phase. The rate constants of the exponential force development $\left(k_{\mathrm{ACT}}\right)$ and the fast phase of relaxation $\left(k_{\mathrm{REL}}\right)$ are fitted with a single exponential function $\left(y(t)=y_{\text {plateau }}+\left(y_{0}-y_{\text {plateau }}\right) \exp (-k t)\right.$, where the parameter $k,\left(k_{\mathrm{ACT}}, k_{\mathrm{TR}}\right.$ or $\left.k_{\mathrm{REL}}\right)$ characterize the rate of the course [55]. In order to determine the rate of myofibril activation in thick specimens, such as cardiomyocytes, a fast length release following quick restretch is applied to cardiac cells or muscle strips and the rate of force redevelopment $\left(k_{\mathrm{TR}}\right)$ that is comparable to $k_{\mathrm{ACT}}$ is measured [56].

\section{Contractile Properties of HCM and DCM Hearts}

\subsection{Decreased Force Capacity}

Hypertrophic cardiomyopathy samples produce significantly lower strength per muscle cross-sectional areas (Figure 1A). The decrease in force in muscle tissue and isolated cardiomyocytes can be partially explained by myofibril disarray [14] and decrease of myofibril density (Figure 1B), but also due to the contractile defects. In fact, the maximal force developed by cardiomyocytes from HCM hearts was lower almost in all studied cases (Figure 1A, Table 1). The mean $F_{\max }$ was $41 \%$ lower than that of healthy donor hearts. At the same time, myofibril density was $20 \%$ lower in HCM cardiomyocytes [14,57-59]. Furthermore, the force produced by single myofibrils from HCM hearts with an identified genetic disease-causing mutation, irrespective of gene (MYBPC3, MYH7, TPM1, TNNT2), was also lower by $24 \%$ than that of control heart myofibrils (Figure 1A). This can suggest that there is some abnormality in cross-bridge cycling kinetics. However, the effect does not have to be purely due to mutation. Other factors as haploinsufficiency and secondary changes such as an altered protein phosphorylation [60], protein oxidation [61-63], and changes in protein isoform expression (see review [64]) cannot be excluded. Indeed, a number of samples with no mutation found in the genes of sarcomeric proteins also showed significantly lower (by 22\%) myofibrillar force [57]. 
Table 1. Contractile characteristics of hypertrophic cardiomyopathy heart muscle.

\begin{tabular}{|c|c|c|c|c|c|c|c|c|c|c|c|c|c|c|c|c|c|c|c|c|c|c|c|c|c|c|c|c|c|c|}
\hline \multirow[b]{3}{*}{ Diagnosis } & \multicolumn{5}{|c|}{$\begin{array}{l}\text { Mutation, Gene Expression and Mutated } \\
\text { (mut) Allele Expression }\end{array}$} & \multirow{2}{*}{\multicolumn{3}{|c|}{$\begin{array}{l}\text { Phosphorylation Level } \\
\text { (Cardiomyopathy/ } \\
\text { Healthy) }\end{array}$}} & \multirow{2}{*}{\multicolumn{2}{|c|}{$\begin{array}{l}\text { Titin Isoforms } \\
\text { and Passive } \\
\text { Stiffness } \\
\text { (Cardiomyopath } \\
\text { y/ } \\
\text { Healthy) }\end{array}$}} & \multicolumn{3}{|c|}{$\begin{array}{l}\text { Maximal Force and } \\
\text { Myofibril Density } \\
\text { (Cardiomyopathy/ } \\
\text { Healthy) }\end{array}$} & \multicolumn{5}{|c|}{$\begin{array}{l}\text { Contractile Kinetics Parameters } \\
\text { (Cardiomyopathy/Healthy) }\end{array}$} & \multicolumn{3}{|c|}{$\begin{array}{l}\mathrm{Ca}^{2} \text {-Sensitivity of } \\
\text { Force } \\
\text { (Cardiomyopathy/ } \\
\text { Healthy) }\end{array}$} & \multicolumn{3}{|c|}{$\begin{array}{c}\text { Length Dependent } \\
\text { Activation Changes } \\
\text { upon Stretch } \\
\text { (Cardiomyopathy/ } \\
\text { Healthy) } \\
\end{array}$} & \multirow{2}{*}{\multicolumn{2}{|c|}{$\begin{array}{l}\text { Effect PKA on } \\
\text { ECso (in } \mu \mathrm{M} \text { ) }\end{array}$}} & \multicolumn{4}{|c|}{$\begin{array}{l}\text { Patient Information } \\
\text { (Sex, Age and Number } \\
\text { of Patients) }\end{array}$} \\
\hline & \multirow[b]{2}{*}{$\begin{array}{c}\text { Gene } \\
\text { with } \\
\text { Mutation } \\
\end{array}$} & \multirow{2}{*}{\multicolumn{2}{|c|}{$\begin{array}{l}\text { Mutation and } \\
\text { Type: Truncated } \\
\text { (T) or Not (NT) } \\
\end{array}$}} & \multicolumn{2}{|c|}{ Expression } & & & & & & \multicolumn{2}{|c|}{ Myocyte } & \multirow{2}{*}{$\begin{array}{c}\begin{array}{c}\text { Myofi } \\
\text { bril }\end{array} \\
F_{\max }\end{array}$} & Activ & ation & & laxation & & & & +PKA & & & +PKA & & & & & & \\
\hline & & & & Gene & $\begin{array}{l}\text { Mut } \\
\text { Allele }\end{array}$ & TnI & МyBP-С & LC2 & $\begin{array}{l}\mathrm{N} 2 \mathrm{AB} / \\
\mathrm{N} 2 \mathrm{~B}\end{array}$ & $\begin{array}{c}\text { Passive } \\
\text { Stiffness }\end{array}$ & $F_{\max }$ & $\begin{array}{l}\text { Myofibril } \\
\text { Density }\end{array}$ & & $k_{A C T}$ & $k_{\text {тR }}$ & $t_{\text {tuN }}$ & $k$ แบ $k$ & $k_{\mathrm{REL}}$ & $E C_{50}$ & $n_{\text {н }}$ & $E C_{50}$ & $\Delta E C_{50}$ & $\Delta F$ & $\Delta E C_{50}$ & $\Delta F$ & $\Delta \mathrm{EC}_{50}$ & $\begin{array}{l}\text { Sex } \\
M / F\end{array}$ & Age & $\mathrm{N}$ & Refs \\
\hline HCM & МҮВРСЗ & $\begin{array}{l}\text { g.T2604A } \\
+C \text { del at } \\
2605\end{array}$ & $\mathrm{~T}$ & $0.64^{*}$ & $0.34 *$ & & & & & & 0.64 & 1 & & & 1.14 & & & & 0.42 & & & & & & & & M & 42 & & {$[65,66]$} \\
\hline $\mathrm{HCM}$ & МУВРСЗ & & $\mathrm{T}$ & & & 0.18 & 0.75 & & & & 0.85 * & & & & & & & & $0.79 *$ & & 0.96 & $0.57^{*}$ & 1.16 & 1.01 & 0.94 & $0.88^{*}$ & $\mathrm{M} / \mathrm{F}$ & $22-69$ & 17 & [67] \\
\hline $\mathrm{HCM}$ & MYBPCC & & $\mathrm{T}$ & 0.67 & & $0.69^{*}$ & 0.82 & & & 1.46 & 0.71 * & & & & & & & & 0.83 * & $0.84 *$ & $\begin{array}{l}0.0 \\
1\end{array}$ & 0.61 * & 1.04 & 1.13 & & & $\mathrm{M} / \mathrm{F}$ & $22-69$ & 17 & [68] \\
\hline $\mathrm{HCM}$ & MYBPC & & T/NT & & & & & & & & 0.68 * & $0.69^{*}$ & $0.85 *$ & & & & & & & 1 & 1 & & & & & & $\mathrm{MF} 3$ & $32-69$ & 28 & [57] \\
\hline $\mathrm{HCM}$ & MYВPCC & p.R502W & NT & $0.8^{*}$ & & & & & & & 0.75 & & & & 1.10 & & & & 0.35 & & & & & & & & $\mathrm{M}$ & 23 & 1 & [65] \\
\hline $\mathrm{HCM}$ & МYВРСС & & NT & & & 0.09 & 0.64 & & & & 0.44 * & & & & & & & & $0.56^{*}$ & & 0.93 & $0.29 *$ & $0.28^{*}$ & $0.18^{*}$ & $0.25 *$ & $1.45^{*}$ & $\mathrm{M} / \mathrm{F} 3$ & $31-51$ & 4 & [67] \\
\hline $\mathrm{HCM}$ & MYH7 & p.R719Q & NT & & & & & & & & 0.79 & & & & 1.16 & & & & 1.01 & & & & & & & & $\mathrm{~F}$ & 27 & 1 & [65] \\
\hline HCM & MYH7 & & NT & & & 0.22 & 0.58 & & & & 0.54 * & & & & & & & & $0.56^{*}$ & & $0.88^{*}$ & $0.26^{*}$ & $0.44 *$ & $0.42 *$ & $0.38 *$ & $0.97 *$ & $\mathrm{M} / \mathrm{F} 2$ & $25-61$ & $4-6$ & [67] \\
\hline fHCM & MYH7 & p.R403Q & NT & & 0.35 * & & & & & 0.93 & 0.3 & & $0.56^{*}$ & $1.92 *$ & $2.02 *$ & $0.75^{*}$ & $4^{*} 1$. & $1.76^{*}$ & & & & & & & & & M & 24 & & [69-71] \\
\hline $\mathrm{fHCM}$ & MYH7 & p.R403Q & NT & & 0.5 & & & & & & 0.6 & & 0.83 & 1.84 & & & $\begin{array}{ll}2.9 & 1\end{array}$ & 1.77 & & & & & & & & & M & 35 & 1 [ & [69-71] \\
\hline fHCM & MYH7 & p.R403Q & NT & & 0.45 & & & & & & 0.6 & & 0.91 & $\begin{array}{l}1.04 \\
1.52\end{array}$ & & & 2.7 & 1.99 & & & & & & & & & $\mathrm{~F}$ & 39 & 1 [ & {$[69-71]$} \\
\hline fHCM & MYH7 & p.R723G & NT & & 0.7 & & & & & & $0.54^{*}$ & & & & & & & & $1.41 *$ & & & & & & & & M & 38,55 & 2 & [72] \\
\hline fHCM & MYH7 & p.R723G & NT & & 0.68 & 0.11 * & $0.42 *$ & $0.42^{*}$ & & $0.72 *$ & 0.69 * & $0.74^{*}$ & & & 0.93 & & & & 1 & & $1.28^{*}$ & & & & & $1.44^{*}$ & $\mathrm{M} / \mathrm{F} 5$ & 53,55 & 2 & {$[73,74]$} \\
\hline fHCM & MYH7 & p.A200V & NT & & 0.53 & & & & & & $0.48^{*}$ & & & & & & & & $1.12 *$ & & & & & & & & $\mathrm{~F}$ & 19 & & {$[72,75]$} \\
\hline fHCM & MYH7 & & NT & & & & & & & & 0.39 * & $0.79 *$ & $0.65 *$ & & & & & & & & 1 & & & & & & $\mathrm{M} / \mathrm{F}$ & $19-61$ & 11 & [57] \\
\hline fHCM & TPM1 & p. $1284 \mathrm{~V}$ & NT & & & & & & & & $0.40^{*}$ & 0.70 * & $0.62 *$ & & & & & & & & & & & & & & $\mathrm{M}$ & 65 & 1 & [57] \\
\hline $\mathrm{HCM}$ & TPM1 & p.M281T & NT & & & 0.07 & 0.55 & & & & $0.48^{*}$ & & & & & & & & $0.67^{*}$ & & 0.95 & $0.39 *$ & 0.72 & $-0.2^{*}$ & $0.06^{*}$ & $1.08^{*}$ & $\mathrm{M}$ & 65 & 1 & [67] \\
\hline $\mathrm{HCM}$ & TNNT2 & p.K280N & NT & & & 0.96 & 1.07 & & & & 0.70 & & & & & & & & $0.80^{*}$ & & $0.76^{*}$ & $0.45^{*}$ & 0.34 & $0.30^{*}$ & $0.15 *$ & 0.12 & M & 26 & 1 & [67] \\
\hline $\mathrm{HCM}$ & TNNT2 & p.K280N & NT & & & & & & & & 0.56 & $0.78^{*}$ & $0.73^{*}$ & & & & & & & & & & & & & & M & 26 & 2 & [57] \\
\hline $\mathrm{HCM}$ & TNNI3 & p.R145W & NT & & & & & & & & 0.55 * & $0.58^{*}$ & 0.84 & & & & & & & & & & & & & & M & 46,66 & 2 & [57] \\
\hline HCM & TNNI3 & p.R145W & NT & & & 0.09 & 0.49 & & & & 0.29 & & & & & & & & 0.88 * & & $1.18^{*}$ & $0.38^{*}$ & $0.03^{*}$ & $0.34^{*}$ & $0.08^{*}$ & $0.99 *$ & $M$ & 46,66 & 2 & [67] \\
\hline HCM & $\begin{array}{c}M Y H 7(2) \\
M Y B P C 3 \\
(1)\end{array}$ & & NT & & & 0.25 * & $0.14 *$ & 0.91 & 0.70 & 0.85 & $0.61^{*}$ & 1 & & & $1.1^{*}$ & & & & $0.49 *$ & 1.26 & & & & & & & $\mathrm{M} / \mathrm{F} 2$ & $23-61$ & & {$[65,70]$} \\
\hline HCM & none & & & & & 0.18 & 0.4 & & & & 0.81 * & & & & & & & & 0.86 * & & 0.93 & $0.49^{*}$ & 1.2 & $1.06^{*}$ & 1.2 & 0.73 & $\mathrm{M} / \mathrm{F}$ & $46-75$ & $3-7$ & [67] \\
\hline $\mathrm{HCM}$ & none & & & & & & 1 & & & & $0.71^{*}$ & $0.92 *$ & $0.78 *$ & & & & & & & & 1 & & & & & & $\mathrm{M} / \mathrm{F} 3$ & $35-75$ & $\begin{array}{l}3- \\
14\end{array}$ & [57] \\
\hline HCM & none & & & & & $0.60^{*}$ & 0.54 * & & & 1 & $0.75^{*}$ & & & & & & & & $0.8^{*}$ & $0.81 *$ & 1 & $0.49^{*}$ & 0.94 & 0.97 & & & $\mathrm{M} / \mathrm{F} 4$ & $46-75$ & $\begin{array}{l}14 \\
11\end{array}$ & [68] \\
\hline $\mathrm{HCM}$ & none & & & & & & & & & & 1.0 & & 0.84 & 1.01 & & & $2.1 \quad 1$ & 1.59 & & & & & & & & & $\mathrm{M} / \mathrm{F}$ & $35-72$ & $\begin{array}{l}11 \\
9\end{array}$ & [71] \\
\hline HCM & none & & & & & & & & & & 0.61 & & & & 1.0 & & & & 0.5 & & & & & & & & M & 59 & 1 & [65] \\
\hline HCM & no & & & & & & & & & & 0.35 & & & & 1.05 & & & & 0.4 & & & & & & & & $\mathrm{~F}$ & 61 & 1 & [65] \\
\hline $\mathrm{HCM}$ & none & & & & & & & & & & $\begin{array}{l}0.33 \\
0.42\end{array}$ & & & & 1.12 & & & & $\begin{array}{l}0.45 \\
0.49\end{array}$ & & & & & & & & M & 58 & 1 & [65] \\
\hline
\end{tabular}

The value changes were normalized to healthy control hearts (Cardiomyopathy/Healthy) if not otherwise specified. The parameters of length dependent activation are shown as a difference in $E C_{50}$ and $F_{\max }$ between long and short sarcomere lengths. Passive stiffness was evaluated as a Young's modulus or as a passive tension generated by muscle at stretch. In some cases, approximate values are given. ${ }^{*} p<0.05$. HCM — hypertrophic cardiomyopathy, fHCM—familial HCM, PKA—protein kinase A. The table cells are highlighted according to the value changes compared to control: yellow—no changes, green—the value decreased, blue-the value increased. 
Table 2. Contractile characteristics of dilated and other cardiomyopathy heart muscles.

\begin{tabular}{|c|c|c|c|c|c|c|c|c|c|c|c|c|c|c|c|c|c|c|c|c|c|c|c|c|c|c|c|c|c|}
\hline \multirow[b]{3}{*}{ Diagnosis } & \multicolumn{5}{|c|}{$\begin{array}{l}\text { Mutation, Gene Expression and Mutated (mut) } \\
\text { Allele Expression }\end{array}$} & \multirow{2}{*}{\multicolumn{3}{|c|}{$\begin{array}{l}\text { Phosphorylation Level } \\
\text { (Cardiomyopathy/ } \\
\text { Healthy) }\end{array}$}} & \multirow{2}{*}{\multicolumn{2}{|c|}{$\begin{array}{c}\text { Titin Isoforms and } \\
\text { Passive Stiffness } \\
\text { (Cardiomyopathy/ } \\
\text { Healthy }\end{array}$}} & \multicolumn{3}{|c|}{$\begin{array}{l}\text { Maximal Force and } \\
\text { Myofibril Density } \\
\text { (Cardiomyopathy/ } \\
\text { Healthy) }\end{array}$} & \multicolumn{5}{|c|}{$\begin{array}{l}\text { Contractile Kinetics Parameters } \\
\text { (Cardiomyopathy/Healthy) }\end{array}$} & \multicolumn{3}{|c|}{$\begin{array}{l}\text { Ca'-Sensitivity of } \\
\text { Force } \\
\text { (Cardiomyopathy/ } \\
\text { Healthy) }\end{array}$} & \multicolumn{3}{|c|}{$\begin{array}{c}\text { Length Dependent } \\
\text { Activation Changes } \\
\text { upon Stretch } \\
\text { (Cardiomyopathy/ } \\
\text { Healthy) }\end{array}$} & \multirow{3}{*}{$\begin{array}{c}\begin{array}{c}\text { Effect } \\
\text { PKA on } \\
\text { EC } \\
-\quad \mu M \text { (in } \\
\end{array} \\
\Delta E C_{50}\end{array}$} & \multicolumn{4}{|c|}{$\begin{array}{l}\text { Patient Information (Sex, } \\
\text { Age and Number of } \\
\text { Patients) }\end{array}$} \\
\hline & \multirow[b]{2}{*}{$\begin{array}{c}\text { Gene } \\
\text { with } \\
\text { Mutation }\end{array}$} & \multicolumn{4}{|c|}{ Expression } & & & & & & \multirow{2}{*}{\multicolumn{2}{|c|}{$\begin{array}{c}\text { Myocyte } \\
\max \begin{array}{c}\text { Myofibril } \\
\text { Density }\end{array}\end{array}$}} & \multirow{2}{*}{$\begin{array}{c}\begin{array}{c}\text { Myofi } \\
\text { bril }\end{array} \\
F_{\max }\end{array}$} & \multicolumn{2}{|c|}{ Activation } & & Relaxatio & & & & +PKA & & & + +PKA & & & & & \\
\hline & & $\begin{array}{l}\text { Mutation and Ty } \\
\text { Truncated (T) or 1 } \\
\text { (NT) }\end{array}$ & & Gene & $\begin{array}{l}\text { Mut } \\
\text { Protein }\end{array}$ & TnI & $\underset{\mathrm{C}}{\mathrm{MyP}-}$ & LC2 & $\begin{array}{l}\mathrm{N} 2 \mathrm{AB} / \\
\mathrm{N} 2 \mathrm{~B}\end{array}$ & $\begin{array}{l}\text { Passive } \\
\text { Stiffness }\end{array}$ & & & & $k_{\text {ACT }}$ & $k$ тR & tuN & $k$ แั & $k_{\mathrm{REL}}$ & $E C_{50}$ & $n$ н & $E C_{50}$ & $\Delta E C_{50}$ & $\Delta F$ & $\Delta E C_{50}$ & & $\begin{array}{l}\text { Sex } \\
M / F\end{array}$ & Age & $\mathrm{N}$ & Refs \\
\hline IDCM & TTN & p. (R23464Tfs $\left.{ }^{*} 41\right)$ & $\mathrm{T}$ & 1.0 & 0 & & & & 1.05 & $0.63^{*}$ & & & 1.02 & 1.05 & 1.06 & 0.97 & 1.06 & 0.91 & & & & & 1.00 & & & $\mathrm{M}$ & 22 & 1 & [76] \\
\hline $\mathrm{fDCM}$ & $T T N$ & p. (R23464Tff* 41$)$ & $\mathrm{T}$ & 1.0 & 0 & & & & 1.11 & $0.66 *$ & & & 0.96 & 1.12 & 0.95 & 0.98 & 0.18 & 1.13 & & & & & 1.13 & & & M & 37 & 1 & {$[76]$} \\
\hline fDCM & $T T N$ & p.(Y18923*) & $\mathrm{T}$ & 0.96 & 0 & & & & 1.25 & 0.62 * & & & 1.04 & 1.15 & $1.16^{*}$ & 0.98 & 1.06 & 1.17 & & & & & 1.03 & & & $\mathrm{~F}$ & 22 & 1 & {$[76]$} \\
\hline PPCM & TTN & p.(K15664Vfs"13) & $\mathrm{T}$ & & & & & & 1.85 & 0.4 & & & & & & & & & & & & & & & & F & & 1 & [77] \\
\hline DCM & LMNA & $\mathrm{p} .(\mathrm{R} 331 \mathrm{Q})$ & NT & & & 0.5 & & & 1.98 * & 1 & 0.64 & 0.63 & & & & & & & $0.86^{*}$ & & 1 & 0.78 & & & & $\mathrm{M} / \mathrm{F}$ & 45.3 & 3 & {$[78,79]$} \\
\hline $\mathrm{fDCM}$ & RMB20 & p.E913K & NT & 0.13 & & & & & 13.89 & 0.8 & 0.85 & & & & & & & & $0.67^{*}$ & 0.58 & 1.13 & 0.36 & & 0.81 & 1.77 & M & 19 & 1 & [80] \\
\hline fDCM & TNNC1 & p.G159D & NT & & & 1.13 & 0.49 & 0.13 & 0.89 & $0.59^{*}$ & 1 & & 1.20 & 0.97 & 0.97 & $0.71^{*}$ & 0.35 & 1.17 & $0.60^{*}$ & $0.59^{*}$ & & & 1.22 & & & M & 3 & 1 & {$[76,81]$} \\
\hline fDCM & TNNI3 & p.K36Q & NT & & & & & & 1.0 & $0.58^{*}$ & & & 1.10 & 1.17 & 1.05 & $0.70^{*}$ & 1.39 & 1.30 * & & & & & 1.34 & & & M & 15 & 1 & [76] \\
\hline IDCM & TNNI3 & p.(R98*) & $\mathrm{T}$ & 0.39 & 0 & 1.08 & & & 1.56 & 1 & 0.95 & & & & & & & & $0.94^{*}$ & & $0.88 *$ & 0.66 & & & & M & 46 & 1 & [78,82] \\
\hline IDCM & TNNT2 & p.(K217del) & NT & 0.51 & & 1.08 & & & 1.64 & $1.3^{*}$ & 1.11 & & & & & & & & 1.07 & & & 0.97 & & & & M & 19 & 1 & {$[78]$} \\
\hline $\mathrm{fDCM}$ & MYH7 & p.E1426K & NT & & & & & & 1.08 & $0.65^{*}$ & & & 0.97 & 1.13 & $1.19^{*}$ & $0.70^{*}$ & 0.76 & $1.35 *$ & & & & & 0.96 & & & $\mathrm{M}$ & 43 & 1 & {$[76]$} \\
\hline IDCM & not stated & & & & & 0.54 & & & 1.98 & 1 & 0.98 & & & & & & & & 0.94 & & 1 & 0.73 & & & & $\mathrm{M} / \mathrm{F}$ & 54.6 & 5 & [78] \\
\hline DCM & not stated & & & & & & & & 1.24 * & $0.27 *$ & & & & & & & & & & & & & & & & & $51-56$ & $3-4$ & [83] \\
\hline DCM & not stated & & & & & 0.5 & & & & & & & & & & & & & 0.51 & 1 & 0.96 & & & & 3.37 & $\mathrm{M}$ & 45,59 & 2 & [84] \\
\hline IDCM & not stated & & & & & 0.35 * & $0.58 *$ & & $1.62 *$ & 1 & 0.94 & & & & & & & & $0.69^{*}$ & & 1.12 & 0.76 & & 1.09 & & & & 8 & [85] \\
\hline IDCM & not stated & & & & & $0.4^{*}$ & $0.4^{*}$ & 1.1 & & & 1.18 & & & & 0.88 & & & & 0.67 & 1.33 & 0.8 & & & & 1.26 & $\mathrm{M} / \mathrm{F}$ & $52-62$ & 7 & [86] \\
\hline IDCM & not stated & & & & & & & & 1.78 & 1.2 & 1.34 & & & & & & & & $0.68 *$ & 0.81 & 0.87 & 0.59 & & 0.86 & 1.33 & & & 3 & [80] \\
\hline IDCM & not stated & & & & & & & & 1.14 & & & & & & & & & & & & & & & & & F & $41-57$ & 6 & [87] \\
\hline PPCM & not stated & & & & & $0.24^{*}$ & $0.61^{*}$ & & 1.58 & $1.39 *$ & 0.84 & & & & & & & & $0.65^{*}$ & & 1.01 & $0.48^{*}$ & & 0.96 & & F & & 6 & [85] \\
\hline ICM & not stated & & & & & & & & & & 0.95 & & & & 0.93 & & & & 0.71 * & $0.83^{*}$ & & & & & & & & 3 & [88] \\
\hline ICM & not stated & & & & & 0.5 & & & & & & & & & & & & & $0.72 *$ & & 0.98 & & & & 2.13 & $\mathrm{M} / \mathrm{F}$ & $41-65$ & 7 & [84] \\
\hline ICM & not stated & & & & & 0.5 & $0.5^{*}$ & & 0.83 & 1 & 1.04 & & & & & & & & $0.70^{*}$ & & 1.11 & 0.96 & & 1.19 & & & & 4 & [85] \\
\hline $\begin{array}{l}\text { ICM (7) } \\
\text { DCM (2) }\end{array}$ & not stated & & & & & 0.5 & & $0.57 *$ & & 1.06 & 1.0 & & & & & & & & 0.66 * & 0.99 & 0.98 & & & & 2.55 * & $\mathrm{M} / \mathrm{F}$ & $41-65$ & 10 & [84] \\
\hline $\mathrm{HF}$ & not stated & & & & & $0.33 *$ & $0.65 *$ & 1 & & $0.53^{*}$ & $\begin{array}{c}0.53 \\
*\end{array}$ & & & & 0.96 & & & & 0.63 * & 0.87 & 0.98 & & & & & $\mathrm{M} / \mathrm{F}$ & $42-57$ & 4 & [89] \\
\hline $\begin{array}{l}\text { IRCM } \\
\text { IRCM }\end{array}$ & $\begin{array}{l}\text { not stated } \\
\text { not stated }\end{array}$ & & & & & & & & & & & & $\begin{array}{l}0.84 \\
1.16\end{array}$ & & & $\begin{array}{l}1.20^{*} \\
1.92^{*}\end{array}$ & $\begin{array}{l}0.05^{*} \\
0.07 *\end{array}$ & $\begin{array}{l}0.52^{*} \\
0.33^{*}\end{array}$ & & & & & & & & $\begin{array}{l}\mathrm{F} \\
\mathrm{M}\end{array}$ & $\begin{array}{l}66 \\
21\end{array}$ & $\begin{array}{l}1 \\
1\end{array}$ & $\begin{array}{l}{[90]} \\
{[90]}\end{array}$ \\
\hline $\begin{array}{l}\text { IDCM (9) } \\
\text { NCC (2) }\end{array}$ & not stated & & & & & $0.27^{*}$ & & & $0.4-2.8$ & $0.7^{*}$ & 0.64 & & & & & & & & & & & $0.67 *$ & & 1 & & & $<18$ & 11 & [58] \\
\hline
\end{tabular}

The value changes were normalized to healthy control hearts (Cardiomyopathy/Healthy) if not otherwise specified. The parameters of length dependent activation are shown as a difference in $E C_{50}$ and $F_{\max }$ between long and short sarcomere length. Passive stiffness was evaluated as a Young's modulus or as a passive tension generated by muscle at stretch. In some cases, approximate values are given. * $p<0.05$. PPCM—peripartum cardiomyopathy, ICM—ischemic cardiomyopathy, RCM—restrictive cardiomyopathy, HF-heart failure, IDCM-idiopathic DCM, fDCM-familial DCM, IRCM-idiopathic restrictive cardiomyopathy. The table cells are highlighted according to the value changes compared to control:

yellow-no changes, green-the value decreased, blue-the value increased. 
With respect to DCM samples, neither cardiomyocytes nor myofibrils produce force significantly different from that of donor hearts, except in one study with mutation in LMNA (lamin A/C; p.(R331Q)) [78,79] (Figure 1C, Table 2), where $F_{\max }$ was lower by $37 \%$ and that was explained by the decrease in myofibril density (Table 2). This means that systolic dysfunction observed in DCM hearts is not caused by the decrease in force production, but is rather due to ventricular dilation. The end-diastolic volume increase causes a decrease in left ventricular ejection fraction [91]. A decrease in myofibril density was also observed in the case of end-stage pediatric cardiomyopathy [58] and congenital dilated cardiomyopathy with mutation in the structural protein filamin-C [92].

A

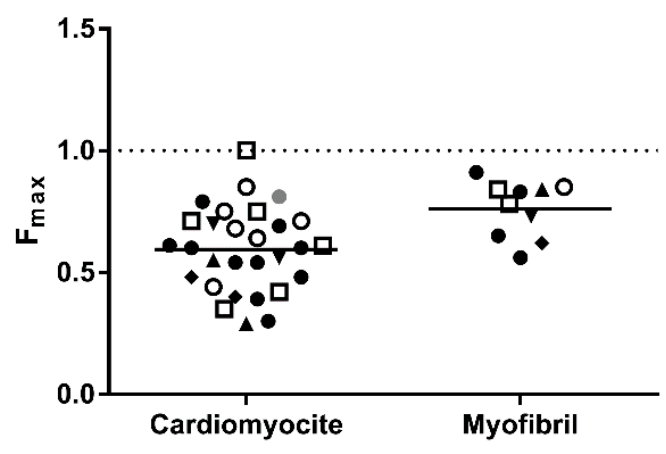

C

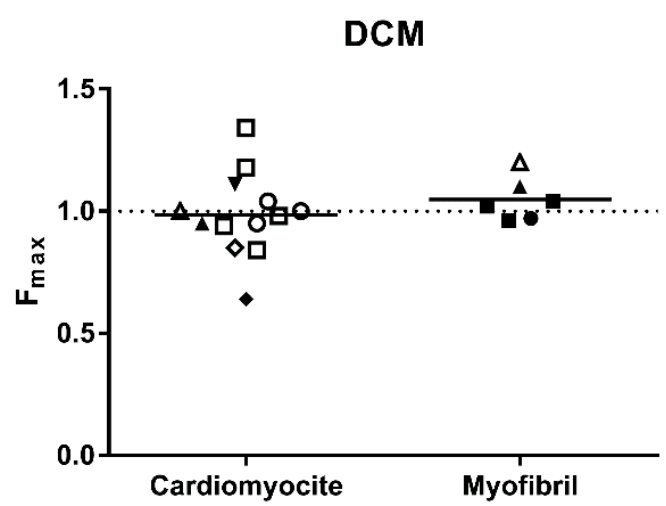

B

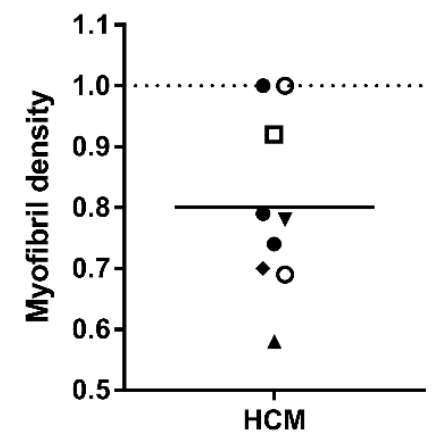

Figure 1. Maximum force of contraction by different types of preparations: from hearts of patients with $\mathrm{HCM}(\mathbf{A})$ and DCM (C). As can be seen, the maximal force generated by cardiomyocytes as well as myofibrils is lower in the HCM samples. The force is not diminished in DCM samples. (B) Density of myofibrils in cells were measured in some HCM samples. Each data point represents a different experimental group where the symbols indicate genes where mutations were found. See also Tables 1 and 2. All values are normalised to those of donor heart muscle (dashed line).

\subsection{Activation and Relaxation Kinetics}

We combined data concerning force development from different papers in Figure 2 and found that the rate of force growth in HCM and DCM samples did not significantly vary from control. Only the samples with mutation in MYH7 R403Q encoding cardiac $\beta$-myosin heavy chain, had significantly higher cross bridge turnover rate characterized by the activation and relaxation rate constants [69]. The authors explained it by faster cross-bridge detachment rates. The relaxation kinetics in single R403Q myofibrils was 1.5 times higher than in sarcomere mutation-negative HCM myofibrils and 1.5-2 times higher than in myofibrils from control hearts [71]. Furthermore, it was found 1.6 times 
higher in the muscle strips of $M Y H 7$ R403Q patients compared to control mutation-negative HCM which showed a positive linear correlation with the slope of slow relaxation phase [71].

Activation kinetics in all studied DCM myofibrils regardless of mutation was not significantly altered. The situation with relaxation was different. Relaxation of DCM samples with truncating mutations in the TTN gene was not different from control, while relaxation was faster in all other studied myofibrils which had mutations in the genes of contractile proteins: myosin (MYH7 E1426K) and troponins (TNNI3 K36Q and TNNC1 G159D).

Interestingly, that in the case with RCM disease, myofibril relaxation was slower (Table 2), contributing to diastolic ventricular dysfunction [90].

A

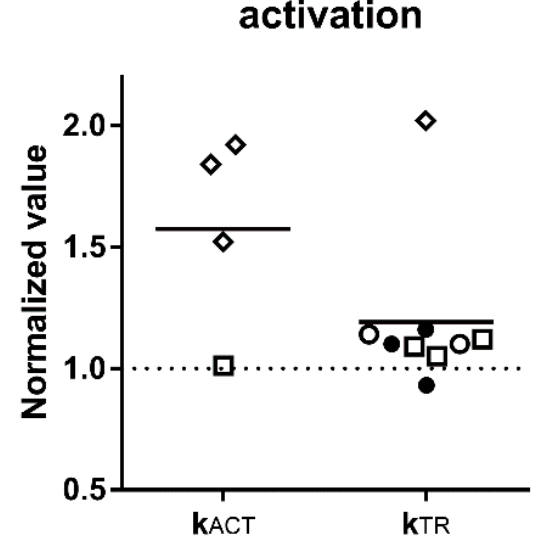

C DCM
activation

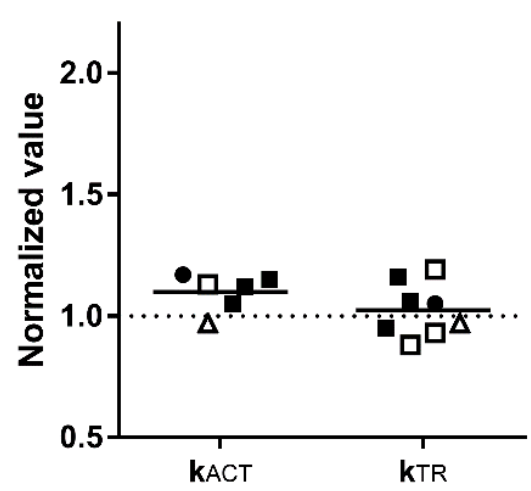

B

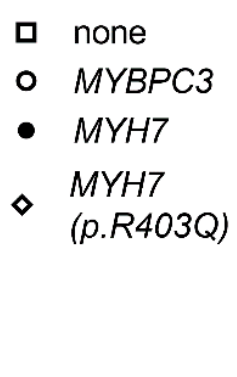

- TTN

$\triangle$ TNNC1

- TNN/3

$\mathrm{MYH7}$

D
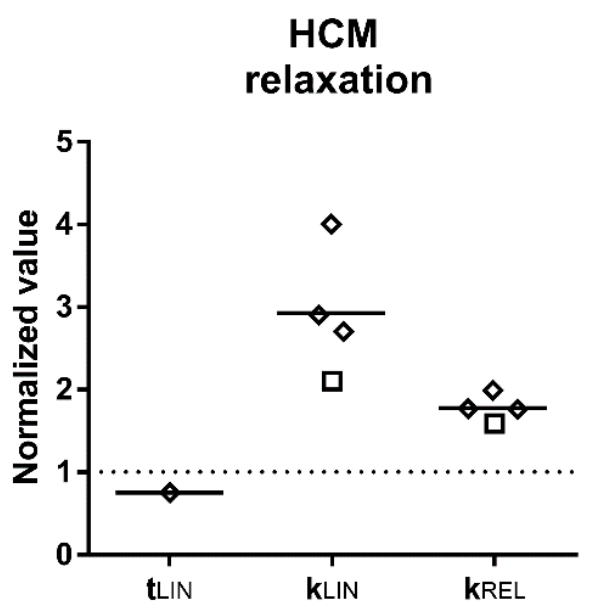

Figure 2. Contractile kinetics parameters. Parameters of activation $(\mathbf{A}, \mathbf{C})$ and relaxation $(\mathbf{B}, \mathbf{D})$ kinetics of HCM and DCM muscle samples. Each data point represents a different experimental group where the symbols indicate genes where mutations were found. All values are normalised to those of donor heart muscle. See also Tables 1 and 2.

\subsection{Elevated $\mathrm{Ca}^{2+}{ }_{-}$Sensitivity}

The $\mathrm{Ca}^{2+}$ sensitivity of DCM and HCM patient heart muscle is usually higher (see Figure 3A,C; $\left.\mathrm{EC}_{50(\mathrm{HCM})} / \mathrm{EC}_{50 \text { (Donor) }}=\mathrm{EC}_{50 \text { (DCM) }} / \mathrm{EC}_{50 \text { (Donor) }}=0.74\right)$ than in muscle of a healthy donor. There is a perception that the difference in $\mathrm{Ca}^{2+}$-sensitivity is mainly due to $\mathrm{TnI}$ dephosphorylation in hearts with cardiomyopathy (Figure 3A,C; 69\% and 31\% lower in HCM and DCM, respectively) and not because of mutations. In normal donor hearts TnI is highly phosphorylated $(0.8-2 \mathrm{~mol} \mathrm{Pi} / \mathrm{mol} \mathrm{TnI})$ and exists mostly in double phosphorylated and single phosphorylated forms. Phosphorylation level is reduced 
in cardiomyopathies $(0.2-1.3 \mathrm{~mol} \mathrm{Pi} / \mathrm{mol} \mathrm{TnI})[68,78,84,85,93,94]$. But what is true in general may be different for some specific cases. For example, phosphorylation of TnI was found rather high in a number of DCM samples where a mutation was found as the cause of the disease: TNNI3 p.98trunc and TNNT2 p.K217del ( 2 mol Pi/mol TnI) [78], ACTC E99K (HCM mutation, $1.61 \mathrm{~mol} \mathrm{Pi/mol} \mathrm{TnI)} \mathrm{[95],}$ TNNC1 G159D (1.53 mol Pi/mol TnI) [81], and TNNT2 K280N (1.4-1.6 mol Pi/mol TnI). It may be the case that idiopathic DCM hearts with found mutations may have normal phosphorylation of TnI, whereas hearts without mutation rather have a reduced phosphorylation level. Alongside with TnI, MyBP-C and myosin light chain 2 (or regulatory) phosphorylation also decreased by 1.5-2.5 folds in hearts with cardiomyopathies [67,73,96-98]. Phosphorylation of MyBP-C may be responsible for about half of the change in $E C_{50}$ at low sarcomere length, but not at high sarcomere length, and is an important factor in length-dependent activation [12].

A

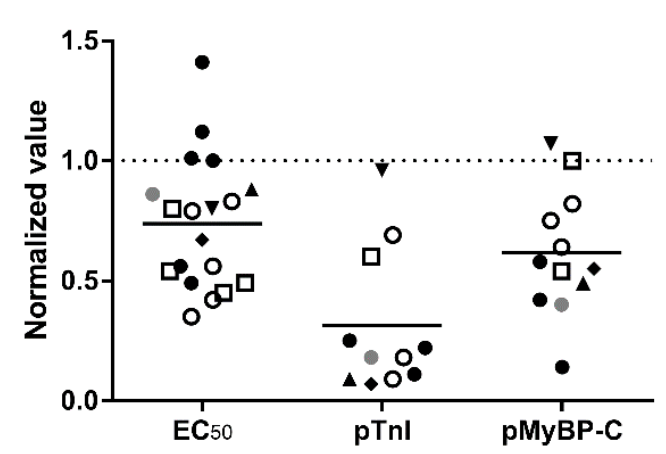

C

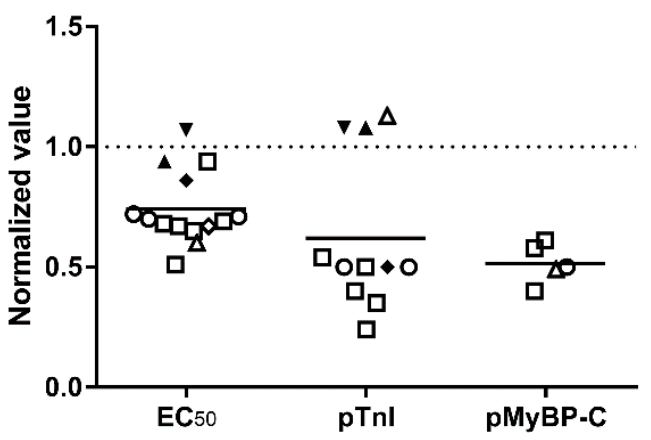

B HCM; effect of PKA

ㅁ none

- $M Y B P C 3$

MYBPC3,

MYH7

- $M Y H 7$

- TNNI3

TNNT2

- TPM1

DCM

- TTN

จ TNNT2

- TNN/3

$\triangle$ TNNC1

$\diamond \quad R M B 20$

- LMNA

- ICM

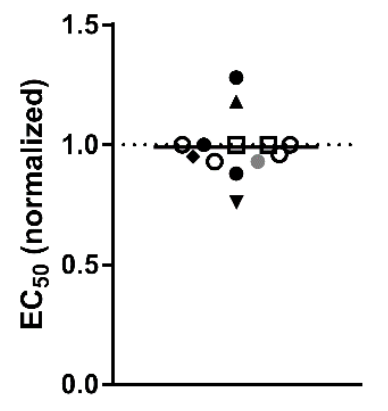

D DCM; effect of PKA

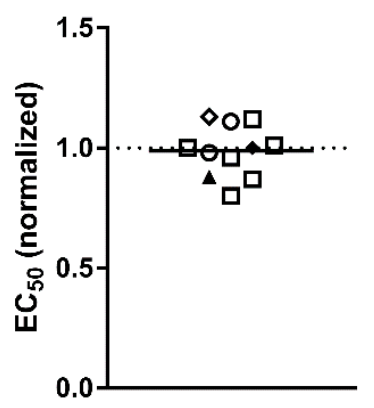

Figure 3. The concentration of $\mathrm{Ca}^{2+}$ required for half-maximal contraction $\left(E C_{50}\right)$ and total phosphorylation level of troponin I (pTnI) and MyBP-C (pMyBP-C) of heart tissue samples. The data are from Tables 1 and 2. The values for $\operatorname{HCM}(\mathbf{A}, \mathbf{B}), \operatorname{DCM}(\mathbf{C}, \mathbf{D})$ are normalized to control donor hearts (dashed line). The effect of PKA treatment on $\mathrm{Ca}^{2+}$-sensitivity of heart muscles from HCM (B) and DCM (D) patients. The $E C_{50}$ values are normalized to the $E C_{50}$ of normal donor heart samples. PKA eliminates or at least lessens the difference between cardiomyopathic and donor hearts. Each data point represents a different experimental group where the symbols indicate genes where mutations were found.

To discriminate the effect of mutation from the secondary effects caused by dephosphorylation of $\mathrm{TnI}$ and MyBP-C, in some experiments skinned muscle samples were treated with protein kinase A (PKA). After PKA treatment, TnI and MyBP-C became phosphorylated to the levels of donor hearts and the difference in $E C_{50}$ between a donor heart and heart with cardiomyopathy was ether fully eliminated or substantially reduced (Figure 3B,D). Little difference in the phosphorylation level could be responsible for the variance seen between some patient samples and healthy subject samples. 


\subsection{Uncoupling of TnI Phosphorylation from the Changes in $\mathrm{Ca}^{2+}$-Sensitivity}

It is well known that phosphorylation of TnI in a normal heart decreases myofilament $\mathrm{Ca}^{2+}$-sensitivity. A case has been made that loss of this functional modulation of $\mathrm{Ca}^{2+}$-sensitivity through phosphorylation of TnI may play a pivotal role in HCM and DCM development and progression. The experiments using reconstituted thin filamnets in the in vitro motility assay provide a strong support that blunted response is one of the common abnormalities seen for both DCM $[76,99,100]$ and HCM mutations [101,102]. It is interesting, that the effect was observed even if pathogenic mutations were not in thin filaments but in other sarcomeric proteins (myosin and MyBP-C) which were not present in the in vitro test system $[76,101]$. Unfortunately, the nature of this blunted response to $\mathrm{TnI}$ phosphorylation has not yet been identified.

On the level of myofibrils there is no robust support that such uncoupling exists. The uncoupling was found in myofibrils prepared with the use of animal models of DCM $[103,104]$ where mutations E361G in actin and G159D in troponin C uncoupled myofibrillar $\mathrm{Ca}^{2+}$-sensitivity changes from TnI phosphorylation.

The evidence obtained from the in vitro experiments with isolated proteins and the studies with the use of animal models [105] is not sufficient. Several studies indicate that uncoupling maybe not an intrinsic property of human HCM [67,73] (Figure 4A). Treatment with PKA decreased $\mathrm{Ca}^{2+}$-sensitivity of human cardiomyocytes with HCM mutations in MYBPC3 and MYH7, as well as with mutations in thin filament proteins: TNNI R145W and TNNT2 K280N. The last mutation was identified earlier as an uncoupling mutation [105]. The results plotted on Figure 4 suggest that treatment with PKA has significantly greater effect on $\mathrm{Ca}^{2+}$-sensitivity in DCM samples (DCM $\triangle E C_{50}$ $\left.=1.93 \mu \mathrm{M} ; \mathrm{HCM} \triangle E C_{50}=0.96 \mu \mathrm{M}\right)$.

A

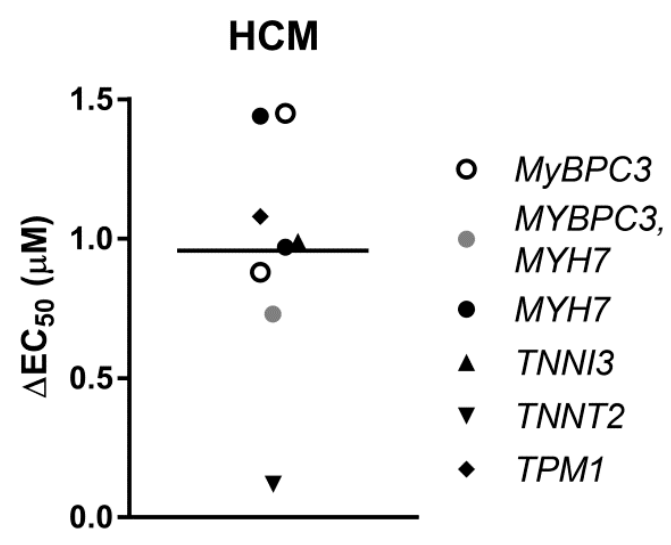

B

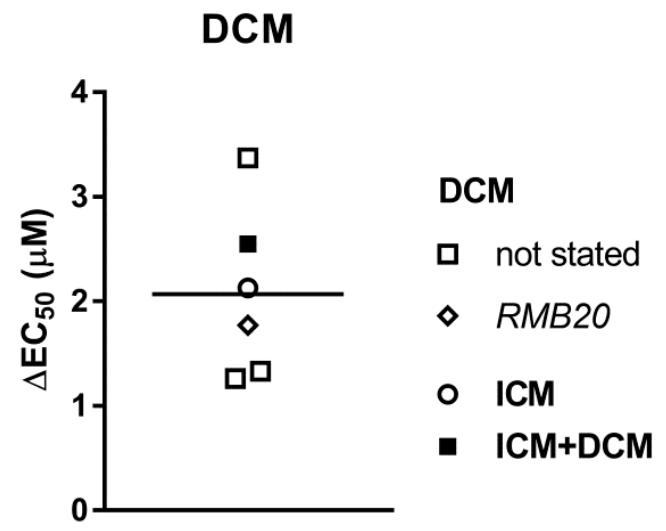

Figure 4. An increase in $E C_{50}$ after phosphorylation with protein kinase A (PKA) for HCM (A) and $\operatorname{DCM}(\mathbf{B})$ muscle samples. Each data point represents a different experimental group where the symbols indicate genes where mutations were found. See also Tables 1 and 2.

\subsection{Length Dependent Activation}

A length dependent activation can be specified as a contribution of a several components. At first, the maximal force is a function of sarcomere length. Secondly, an increase in sarcomere length considerably shifts the force- $\left[\mathrm{Ca}^{2+}\right]$ curve to the left to lower concentrations of $\mathrm{Ca}^{2+}$. The increase in $\mathrm{Ca}^{2+}$-sensitivity, in turn, will enhance the rate of contractility. Additionally, the viscoelastic properties also significantly contribute to the total force production. Neither rate of force development $\left(k_{\mathrm{ACT}}\right.$, $\left.k_{\mathrm{TR}}\right)$ [106] nor relaxation kinetics constants $\left(t_{\mathrm{LIN}}, k_{\mathrm{LIN}}, k_{\mathrm{REL}}\right)$ are sarcomere length dependent [76].

It has been shown that length dependent activation was decreased in HCM samples (Figure 5A). The decrease in $E_{50}$ for $\mathrm{Ca}^{2+}$ following sarcomere length increase was reduced in $\mathrm{HCM}$ samples by 
about $56 \%$. Furthermore, the length dependence of force was decreased by $32 \%$. Admittedly, it is rather unusual that length dependent increase of force was fully diminished in patients with mutations in the genes of troponins TNNI3 and TNNT2. In DCM muscles, length dependent activation was less affected: the change in $\triangle E C_{50}$ decreased by $30 \%$ and the force was unchanged (Figure $5 \mathrm{~B}$ ).

A

\section{HCM}

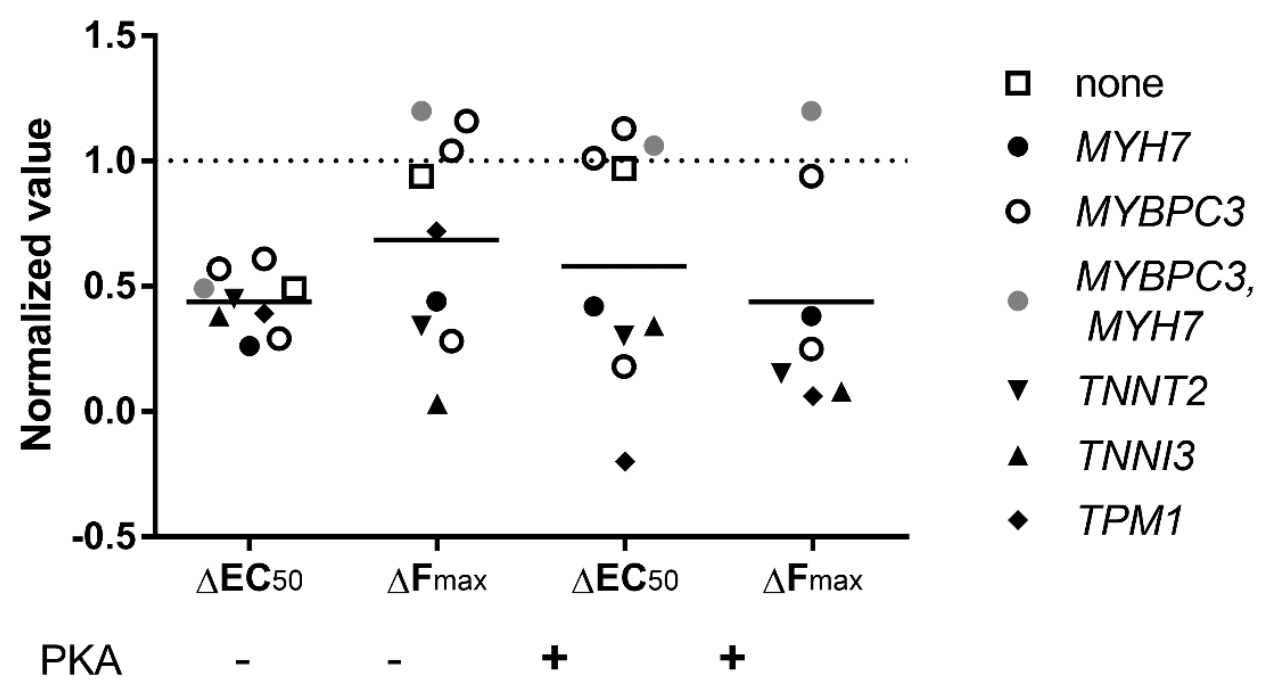

B

DCM

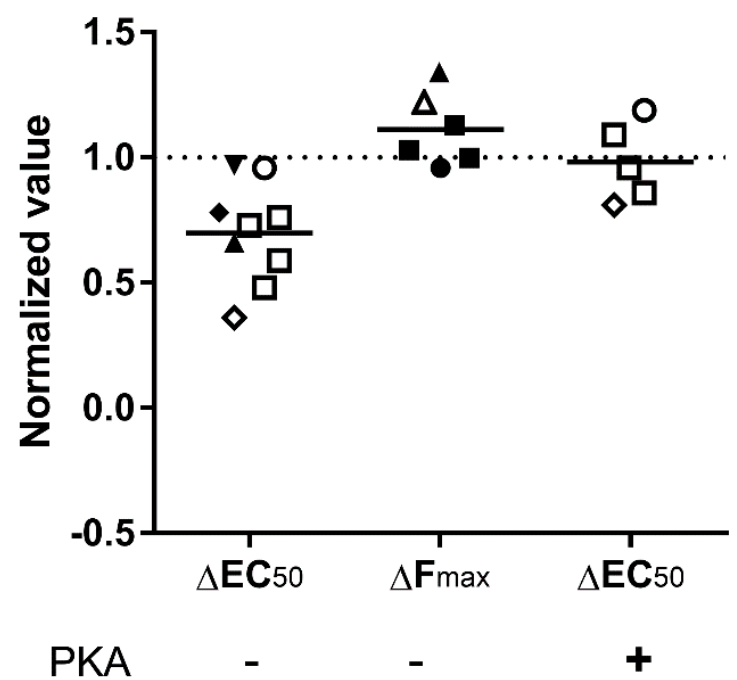

\section{DCM}

口 not stated

- TTN

$\checkmark \quad T N N T 2$

- TNNI3

$\triangle$ TNNC1

$\diamond \quad R M B 20$

- LMNA

- $M Y H 7$

○ ICM

Figure 5. Length dependent activation in cardiac muscle. An increase in sarcomere length decreases $E C_{50}$ and increases $F_{\max }$. Each data point represents a different experimental group where the symbols indicate genes where mutations were found. The values for HCM (A) and DCM (B) are normalized to control donor hearts (dashed line). The data is from Tables 1 and 2.

There are a number of facts suggesting that the length dependent shift in $\mathrm{Ca}^{2+}$-sensitivity was blunted in HCM samples due to the low phosphorylation status of the proteins potentially capable to modulate $\mathrm{Ca}^{2+}$-sensitivity: TnI and MyBP-C. Protein kinase A treatment fully restored length 
dependent activation to a normal level in half of the studies (Figure 5A). A decrease in levels of TnI phosphorylation correlates with a decrease of length dependent activation in DCM samples $[48,64]$ (Figure 5B). MyBP-C phosphorylation (at Ser 275, 284, and 304) was also implied as an important factor capable to modify $\mathrm{Ca}^{2+}$-sensitivity and length dependence activation [77]. In this connection we would like to note the fact that HCM samples with truncations and missense mutations in the MYBPC3 gene show haploinsufficiency of MyBP-C. MyBP-C protein level in these samples was lower by about $30 \%[66,107,108]$. The putative truncated MyBP-C variants were not detected in cardiac tissue samples by Western blot [109]. It suggests protein expression is very low or such mutant proteins undergo degradation in the ubiquitin-proteasome proteolytic pathway [110]. Such overloading of the ubiquitin-proteasome is one of the putative factors to initiate the disease.

\subsection{Passive Stiffness}

Titin is the major contributor to myofibril elasticity, and it is the main force component during diastole accumulating the potential energy of stretch and discharging it during systole. It was shown that passive myofibrillar stiffness was not substantially changed in HCM (Figure 6A, Table 1). Dilated cardiomyopathy-linked mutations in TTN and other sarcomeric proteins as well as with no found mutations decrease titin elasticity characterized by a decrease in myofibrillar stiffness by about $26 \%$ (Figure $6 \mathrm{~B}$, Table 2) $[76,111,112]$. The puzzling thing here is that putative truncated variants were not found in myofibril sarcomeres $[76,113]$. In some cases, the decrease in passive stiffness was, to some extent, explained by altered titin isoform expression [111,112]. However, in many cases there was no correlation between passive stiffness and differential titin isoform expression (Table 2). The slack or resting sarcomere length of DCM myocytes or myofibrils was matching to control $[76,80,85]$, with a difference only found with RMB20 E913K mutation, where expression of the highly compliant N2BA titin isoform was several times higher [80]. The resting sarcomere length in HCM myocytes was similar to control [69] or slightly shorter in some cases [65].

A

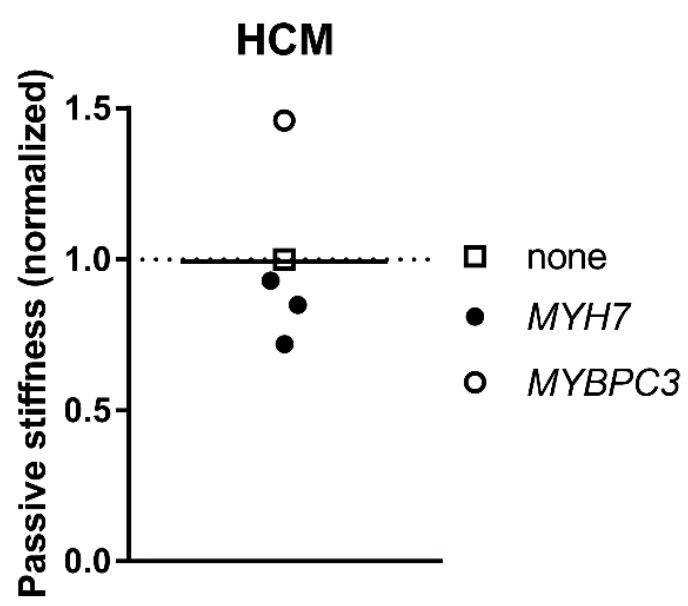

B

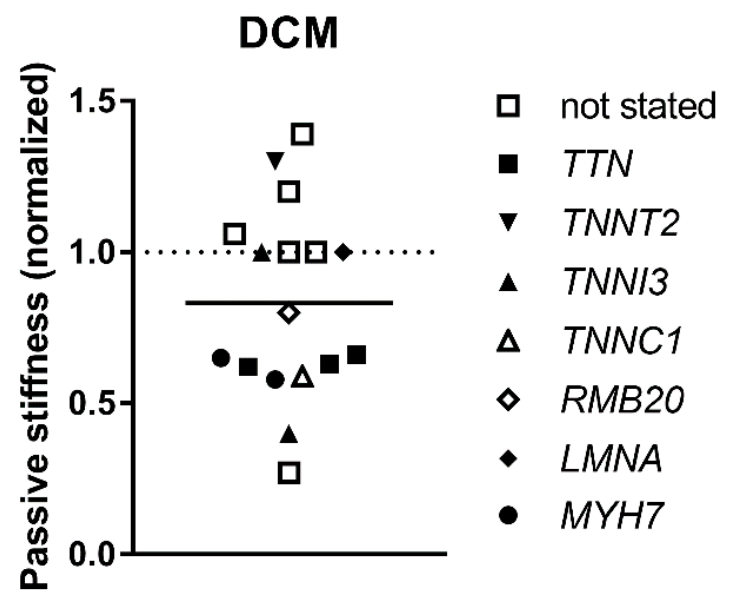

Figure 6. Passive stiffness. Passive stiffness was evaluated as a Young's modulus or as a passive tension generated by muscle at stretch. Each data point represents a different experimental group where the symbols indicate genes where mutations were found. The values for HCM (A) and DCM (B) are normalized to control donor hearts (dashed line). The data is from Tables 1 and 2.

\section{Conclusions}

In this review we tried to analyze data from different studies to show some main correlations between the mutations in the sarcomere proteins or their modification associated with different types of cardiomyopathies and the contractile properties of heart muscle from HCM and DCM patients. 
Data from Table 1 shows that the inability of HCM cardiac myofibrils to generate the same force as controls is one of the essential differences between HCM and DCM muscles (Figure 1A,C). As defined, maximal force depends on the number of force-generating myosin heads and the rates of myosin cross-bridge attachments and detachments [114]. It is assumed that the increase of cross-bridge detachment rate leads to the detrimental increase in the energetic cost of contraction that may be the underlying mechanism of HCM. This hypothesis requires further research by testing contractility and the efficiency of ATP consumption in human cardiac muscles with different HCM mutations. The decrease of force was not observed for DCM myofibrils, but the rate of relaxation was also higher in samples with mutations in the contractile proteins (Figure 2D) [76].

The diastolic intracellular concentration of $\mathrm{Ca}^{2+}$ is about $0.2 \mu \mathrm{M}$ and it increases to about $1.5 \mu \mathrm{M}$ in systole [115-117]. An impaired contractility in $\mathrm{HCM}$ may be compensated by increased $\mathrm{Ca}^{2+}$-sensitivity regulated via dephosphorylation of TnI. Although an increase in $\mathrm{Ca}^{2+}$-sensitivity is the main feature of all cardiomyopathies and heart failure, dephosphorylation of TnI was the major factor responsible for this increase (Figure 3). Therefore, it is essential here to differentiate the direct effect of mutations in proteins on myofibril contractility from other secondary effects. It was proposed that high myofilament $\mathrm{Ca}^{2+}$-sensitivity slows myofibril relaxation in diastole $[8,118,119]$. Furthermore, it is interesting to investigate if the coupling between changes in TnI phosphorylation and the $\mathrm{Ca}^{2+}$-sensitivity of force in HCM and DCM myofibrils is reduced, particularly if a mutation was found in thin filaments. Additionally, titin mechanical properties are believed to be involved to the work output characteristic of myocardium. The decrease of titin originated stiffnes can cause systolic dysfunction in DCM heart muscles [76,112].

Funding: This work was funded the British Heart Foundation (PG/17/5/32705) and supported by The Magdi Yacoub Institute (Charity number: 1082750)

Conflicts of Interest: The authors declare no conflict of interest.

\section{References}

1. Gordan, R.; Gwathmey, J.K.; Xie, L.H. Autonomic and endocrine control of cardiovascular function. World J. Cardiol. 2015, 7, 204-214. [CrossRef] [PubMed]

2. MacLeod, K.T. Recent advances in understanding cardiac contractility in health and disease. F1000Research 2016, 5. [CrossRef] [PubMed]

3. Eisner, D.A.; Caldwell, J.L.; Kistamas, K.; Trafford, A.W. Calcium and Excitation-Contraction Coupling in the Heart. Circ. Res. 2017, 121, 181-195. [CrossRef] [PubMed]

4. Moore, J.R.; Campbell, S.G.; Lehman, W. Structural determinants of muscle thin filament cooperativity. Arch. Biochem. Biophys. 2016, 594, 8-17. [CrossRef] [PubMed]

5. Risi, C.; Eisner, J.; Belknap, B.; Heeley, D.H.; White, H.D.; Schroder, G.F.; Galkin, V.E. Ca(2+)-induced movement of tropomyosin on native cardiac thin filaments revealed by cryoelectron microscopy. Proc. Natl. Acad. Sci. USA 2017, 114, 6782-6787. [CrossRef] [PubMed]

6. Layland, J.; Solaro, R.J.; Shah, A.M. Regulation of cardiac contractile function by troponin I phosphorylation. Cardiovasc. Res. 2005, 66, 12-21. [CrossRef] [PubMed]

7. Wijnker, P.J.; Murphy, A.M.; Stienen, G.J;; van der Velden, J. Troponin I phosphorylation in human myocardium in health and disease. Neth. Heart J. 2014, 22, 463-469. [CrossRef] [PubMed]

8. Marston, S.B. Why Is there a Limit to the Changes in Myofilament $\mathrm{Ca}(2+)$-Sensitivity Associated with Myopathy Causing Mutations? Front. Physiol. 2016, 7, 415. [CrossRef] [PubMed]

9. Craig, R.; Lee, K.H.; Mun, J.Y.; Torre, I.; Luther, P.K. Structure, sarcomeric organization, and thin filament binding of cardiac myosin-binding protein-C. Pflugers Arch. 2014, 466, 425-431. [CrossRef] [PubMed]

10. Yadav, S.; Szczesna-Cordary, D. Pseudophosphorylation of cardiac myosin regulatory light chain: A promising new tool for treatment of cardiomyopathy. Biophys. Rev. 2017, 9, 57-64. [CrossRef] [PubMed]

11. Kampourakis, T.; Yan, Z.; Gautel, M.; Sun, Y.B.; Irving, M. Myosin binding protein-C activates thin filaments and inhibits thick filaments in heart muscle cells. Proc. Natl. Acad. Sci. USA 2014, 111, 18763-18768. [CrossRef] [PubMed] 
12. Kumar, M.; Govindan, S.; Zhang, M.; Khairallah, R.J.; Martin, J.L.; Sadayappan, S.; de Tombe, P.P. Cardiac Myosin-binding Protein C and Troponin-I Phosphorylation Independently Modulate Myofilament Length-dependent Activation. J. Biol. Chem. 2015, 290, 29241-29249. [CrossRef] [PubMed]

13. Papadakis, M.; Sharma, S.; Cox, S.; Sheppard, M.N.; Panoulas, V.F.; Behr, E.R. The magnitude of sudden cardiac death in the young: A death certificate-based review in England and Wales. Europace 2009, 11, 1353-1358. [CrossRef] [PubMed]

14. Hughes, S.E.; McKenna, W.J. New insights into the pathology of inherited cardiomyopathy. Heart 2005, 91, 257-264. [CrossRef] [PubMed]

15. Rapezzi, C.; Arbustini, E.; Caforio, A.L.; Charron, P.; Gimeno-Blanes, J.; Helio, T.; Linhart, A.; Mogensen, J.; Pinto, Y.; Ristic, A.; et al. Diagnostic work-up in cardiomyopathies: Bridging the gap between clinical phenotypes and final diagnosis. A position statement from the ESC Working Group on Myocardial and Pericardial Diseases. Eur. Heart J. 2013, 34, 1448-1458. [CrossRef] [PubMed]

16. Towbin, J.A.; Bowles, N.E. The failing heart. Nature 2002, 415, 227-233. [CrossRef] [PubMed]

17. McKenna, W.J.; Maron, B.J.; Thiene, G. Classification, Epidemiology, and Global Burden of Cardiomyopathies. Circ. Res. 2017, 121, 722-730. [CrossRef] [PubMed]

18. Abelmann, W.H.; Lorell, B.H. The challenge of cardiomyopathy. J. Am. Coll. Cardiol. 1989, 13, 1219-1239. [CrossRef]

19. Haas, J.; Frese, K.S.; Peil, B.; Kloos, W.; Keller, A.; Nietsch, R.; Feng, Z.; Muller, S.; Kayvanpour, E.; Vogel, B.; et al. Atlas of the clinical genetics of human dilated cardiomyopathy. Eur. Heart J. 2015, 36, 1123-1135. [CrossRef] [PubMed]

20. Burke, M.A.; Cook, S.A.; Seidman, J.G.; Seidman, C.E. Clinical and Mechanistic Insights Into the Genetics of Cardiomyopathy. J. Am. Coll. Cardiol. 2016, 68, 2871-2886. [CrossRef] [PubMed]

21. Deo, R.; Albert, C.M. Epidemiology and genetics of sudden cardiac death. Circulation 2012, 125, 620-637. [CrossRef] [PubMed]

22. Konstam, M.A.; Abboud, F.M. Ejection Fraction: Misunderstood and Overrated (Changing the Paradigm in Categorizing Heart Failure). Circulation 2017, 135, 717-719. [CrossRef] [PubMed]

23. Hughes, S.E. The pathology of hypertrophic cardiomyopathy. Histopathology 2004, 44, 412-427. [CrossRef] [PubMed]

24. Basso, C.; Burke, M.; Fornes, P.; Gallagher, P.J.; de Gouveia, R.H.; Sheppard, M.; Thiene, G.; van der Wal, A.; Association for European Cardiovascular, Pathology. Guidelines for autopsy investigation of sudden cardiac death. Virchows Arch. 2008, 452, 11-18. [CrossRef] [PubMed]

25. Mathew, T.; Williams, L.; Navaratnam, G.; Rana, B.; Wheeler, R.; Collins, K.; Harkness, A.; Jones, R.; Knight, D.; O'Gallagher, K.; et al. Diagnosis and assessment of dilated cardiomyopathy: A guideline protocol from the British Society of Echocardiography. Echo Res. Pract. 2017, 4, G1-G13. [CrossRef] [PubMed]

26. Pantazis, A.; Vischer, A.S.; Perez-Tome, M.C.; Castelletti, S. Diagnosis and management of hypertrophic cardiomyopathy. Echo Res. Pract. 2015, 2, R45-R53. [CrossRef] [PubMed]

27. Sankaranarayanan, R.; Fleming, E.J.; Garratt, C.J. Mimics of Hypertrophic Cardiomyopathy-Diagnostic Clues to Aid Early Identification of Phenocopies. Arrhythm. Electrophysiol. Rev. 2013, 2, 36-40. [CrossRef] [PubMed]

28. Bozkurt, B.; Colvin, M.; Cook, J.; Cooper, L.T.; Deswal, A.; Fonarow, G.C.; Francis, G.S.; Lenihan, D.; Lewis, E.F.; McNamara, D.M.; et al. Current Diagnostic and Treatment Strategies for Specific Dilated Cardiomyopathies: A Scientific Statement From the American Heart Association. Circulation 2016, 134, e579-e646. [CrossRef] [PubMed]

29. Japp, A.G.; Gulati, A.; Cook, S.A.; Cowie, M.R.; Prasad, S.K. The Diagnosis and Evaluation of Dilated Cardiomyopathy. J. Am. Coll. Cardiol. 2016, 67, 2996-3010. [CrossRef] [PubMed]

30. Elliott, P.; Andersson, B.; Arbustini, E.; Bilinska, Z.; Cecchi, F.; Charron, P.; Dubourg, O.; Kuhl, U.; Maisch, B.; McKenna, W.J.; et al. Classification of the cardiomyopathies: A position statement from the European Society Of Cardiology Working Group on Myocardial and Pericardial Diseases. Eur. Heart J. 2008, 29, 270-276. [CrossRef] [PubMed] 
31. Pinto, Y.M.; Elliott, P.M.; Arbustini, E.; Adler, Y.; Anastasakis, A.; Bohm, M.; Duboc, D.; Gimeno, J.; de Groote, P.; Imazio, M.; et al. Proposal for a revised definition of dilated cardiomyopathy, hypokinetic non-dilated cardiomyopathy, and its implications for clinical practice: A position statement of the ESC working group on myocardial and pericardial diseases. Eur. Heart J. 2016, 37, 1850-1858. [CrossRef] [PubMed]

32. Ware, J.S.; Amor-Salamanca, A.; Tayal, U.; Govind, R.; Serrano, I.; Salazar-Mendiguchia, J.; Garcia-Pinilla, J.M.; Pascual-Figal, D.A.; Nunez, J.; Guzzo-Merello, G.; et al. Genetic Etiology for Alcohol-Induced Cardiac Toxicity. J. Am. Coll. Cardiol. 2018, 71, 2293-2302. [CrossRef] [PubMed]

33. Linschoten, M.; Teske, A.J.; Baas, A.F.; Vink, A.; Dooijes, D.; Baars, H.F.; Asselbergs, F.W. Truncating Titin (TTN) Variants in Chemotherapy-Induced Cardiomyopathy. J. Card. Fail. 2017, 23, 476-479. [CrossRef] [PubMed]

34. Bakalakos, A.; Ritsatos, K.; Anastasakis, A. Current perspectives on the diagnosis and management of dilated cardiomyopathy Beyond heart failure: A Cardiomyopathy Clinic Doctor's point of view. Hellenic J. Cardiol. 2018. [CrossRef] [PubMed]

35. Felker, G.M.; Thompson, R.E.; Hare, J.M.; Hruban, R.H.; Clemetson, D.E.; Howard, D.L.; Baughman, K.L.; Kasper, E.K. Underlying causes and long-term survival in patients with initially unexplained cardiomyopathy. N. Engl. J. Med. 2000, 342, 1077-1084. [CrossRef] [PubMed]

36. Towbin, J.A.; Lowe, A.M.; Colan, S.D.; Sleeper, L.A.; Orav, E.J.; Clunie, S.; Messere, J.; Cox, G.F.; Lurie, P.R.; Hsu, D.; et al. Incidence, causes, and outcomes of dilated cardiomyopathy in children. JAMA 2006, 296, 1867-1876. [CrossRef] [PubMed]

37. Herman, D.S.; Lam, L.; Taylor, M.R.; Wang, L.; Teekakirikul, P.; Christodoulou, D.; Conner, L.; DePalma, S.R.; McDonough, B.; Sparks, E.; et al. Truncations of titin causing dilated cardiomyopathy. N. Engl. J. Med. 2012, 366, 619-628. [CrossRef] [PubMed]

38. Schafer, S.; de Marvao, A.; Adami, E.; Fiedler, L.R.; Ng, B.; Khin, E.; Rackham, O.J.; van Heesch, S.; Pua, C.J.; Kui, M.; et al. Titin-truncating variants affect heart function in disease cohorts and the general population. Nat. Genet. 2017, 49, 46-53. [CrossRef] [PubMed]

39. Tayal, U.; Newsome, S.; Buchan, R.; Whiffin, N.; Halliday, B.; Lota, A.; Roberts, A.; Baksi, A.J.; Voges, I.; Midwinter, W.; et al. Phenotype and Clinical Outcomes of Titin Cardiomyopathy. J. Am. Coll. Cardiol. 2017, 70, 2264-2274. [CrossRef] [PubMed]

40. Begay, R.L.; Graw, S.; Sinagra, G.; Merlo, M.; Slavov, D.; Gowan, K.; Jones, K.L.; Barbati, G.; Spezzacatene, A.; Brun, F.; et al. Role of Titin Missense Variants in Dilated Cardiomyopathy. J. Am. Heart Assoc. 2015, 4, e002645. [CrossRef] [PubMed]

41. Van Velzen, H.G.; Schinkel, A.F.L.; Baart, S.J.; Oldenburg, R.A.; Frohn-Mulder, I.M.E.; van Slegtenhorst, M.A.; Michels, M. Outcomes of Contemporary Family Screening in Hypertrophic Cardiomyopathy. Circ. Genom. Precis. Med. 2018, 11, e001896. [PubMed]

42. Mathew, J.; Zahavich, L.; Lafreniere-Roula, M.; Wilson, J.; George, K.; Benson, L.; Bowdin, S.; Mital, S. Utility of genetics for risk stratification in pediatric hypertrophic cardiomyopathy. Clin. Genet. 2018, 93, 310-319. [CrossRef] [PubMed]

43. Lopes, L.R.; Syrris, P.; Guttmann, O.P.; O’Mahony, C.; Tang, H.C.; Dalageorgou, C.; Jenkins, S.; Hubank, M.; Monserrat, L.; McKenna, W.J.; et al. Novel genotype-phenotype associations demonstrated by high-throughput sequencing in patients with hypertrophic cardiomyopathy. Heart 2015, 101, $294-301$. [CrossRef] [PubMed]

44. Van Driest, S.L.; Vasile, V.C.; Ommen, S.R.; Will, M.L.; Tajik, A.J.; Gersh, B.J.; Ackerman, M.J. Myosin binding protein $\mathrm{C}$ mutations and compound heterozygosity in hypertrophic cardiomyopathy. J. Am. Coll. Cardiol. 2004, 44, 1903-1910. [CrossRef] [PubMed]

45. Kaski, J.P.; Syrris, P.; Esteban, M.T.; Jenkins, S.; Pantazis, A.; Deanfield, J.E.; McKenna, W.J.; Elliott, P.M. Prevalence of sarcomere protein gene mutations in preadolescent children with hypertrophic cardiomyopathy. Circ. Cardiovasc. Genet. 2009, 2, 436-441. [CrossRef] [PubMed]

46. Millat, G.; Bouvagnet, P.; Chevalier, P.; Dauphin, C.; Jouk, P.S.; Da Costa, A.; Prieur, F.; Bresson, J.L.; Faivre, L.; Eicher, J.C.; et al. Prevalence and spectrum of mutations in a cohort of 192 unrelated patients with hypertrophic cardiomyopathy. Eur. J. Med. Genet. 2010, 53, 261-267. [CrossRef] [PubMed] 
47. Mazzarotto, F.; Girolami, F.; Boschi, B.; Barlocco, F.; Tomberli, A.; Baldini, K.; Coppini, R.; Tanini, I.; Bardi, S.; Contini, E.; et al. Defining the diagnostic effectiveness of genes for inclusion in panels: The experience of two decades of genetic testing for hypertrophic cardiomyopathy at a single center. Genet. Med. 2018. [CrossRef] [PubMed]

48. Authors/Task Force Members; Elliott, P.M.; Anastasakis, A.; Borger, M.A.; Borggrefe, M.; Cecchi, F.; Charron, P.; Hagege, A.A.; Lafont, A.; Limongelli, G.; et al. 2014 ESC Guidelines on diagnosis and management of hypertrophic cardiomyopathy: The Task Force for the Diagnosis and Management of Hypertrophic Cardiomyopathy of the European Society of Cardiology (ESC). Eur. Heart J. 2014, 35, 2733-2779. [CrossRef] [PubMed]

49. Alfares, A.A.; Kelly, M.A.; McDermott, G.; Funke, B.H.; Lebo, M.S.; Baxter, S.B.; Shen, J.; McLaughlin, H.M.; Clark, E.H.; Babb, L.J.; et al. Results of clinical genetic testing of 2912 probands with hypertrophic cardiomyopathy: Expanded panels offer limited additional sensitivity. Genet. Med. 2015, 17, 880-888. [CrossRef] [PubMed]

50. Mademont-Soler, I.; Mates, J.; Yotti, R.; Espinosa, M.A.; Perez-Serra, A.; Fernandez-Avila, A.I.; Coll, M.; Mendez, I.; Iglesias, A.; Del Olmo, B.; et al. Additional value of screening for minor genes and copy number variants in hypertrophic cardiomyopathy. PLoS ONE 2017, 12, e0181465. [CrossRef] [PubMed]

51. Dos Remedios, C.G.; Lal, S.P.; Li, A.; McNamara, J.; Keogh, A.; Macdonald, P.S.; Cooke, R.; Ehler, E.; Knoll, R.; Marston, S.B.; et al. The Sydney Heart Bank: Improving translational research while eliminating or reducing the use of animal models of human heart disease. Biophys. Rev. 2017, 9, 431-441. [CrossRef] [PubMed]

52. Ait Mou, Y.; Bollensdorff, C.; Cazorla, O.; Magdi, Y.; de Tombe, P.P. Exploring cardiac biophysical properties. Glob. Cardiol. Sci. Pract. 2015, 2015, 10. [PubMed]

53. Poggesi, C.; Tesi, C.; Stehle, R. Sarcomeric determinants of striated muscle relaxation kinetics. Pflugers Arch. 2005, 449, 505-517. [CrossRef] [PubMed]

54. Stehle, R.; Solzin, J.; Iorga, B.; Poggesi, C. Insights into the kinetics of $\mathrm{Ca}^{2+}$-regulated contraction and relaxation from myofibril studies. Pflugers Arch. 2009, 458, 337-357. [CrossRef] [PubMed]

55. Vikhorev, P.G.; Ferenczi, M.A.; Marston, S.B. Instrumentation to study myofibril mechanics from static to artificial simulations of cardiac cycle. MethodsX 2016, 3, 156-170. [CrossRef] [PubMed]

56. Brenner, B. Effect of $\mathrm{Ca} 2+$ on cross-bridge turnover kinetics in skinned single rabbit psoas fibers: Implications for regulation of muscle contraction. Proc. Natl. Acad. Sci. USA 1988, 85, 3265-3269. [CrossRef] [PubMed]

57. Witjas-Paalberends, E.R.; Piroddi, N.; Stam, K.; van Dijk, S.J.; Oliviera, V.S.; Ferrara, C.; Scellini, B.; Hazebroek, M.; ten Cate, F.J.; van Slegtenhorst, M.; et al. Mutations in MYH7 reduce the force generating capacity of sarcomeres in human familial hypertrophic cardiomyopathy. Cardiovasc. Res. 2013, 99, $432-441$. [CrossRef] [PubMed]

58. Bollen, I.A.E.; van der Meulen, M.; de Goede, K.; Kuster, D.W.D.; Dalinghaus, M.; van der Velden, J. Cardiomyocyte Hypocontractility and Reduced Myofibril Density in End-Stage Pediatric Cardiomyopathy. Front. Physiol. 2017, 8, 1103. [CrossRef] [PubMed]

59. Zimmer, G.; Zimmermann, R.; Hess, O.M.; Schneider, J.; Kubler, W.; Krayenbuehl, H.P.; Hagl, S.; Mall, G. Decreased concentration of myofibrils and myofiber hypertrophy are structural determinants of impaired left ventricular function in patients with chronic heart diseases: A multiple logistic regression analysis. J. Am. Coll. Cardiol. 1992, 20, 1135-1142. [CrossRef]

60. Van Dijk, S.J.; Holewijn, R.A.; Tebeest, A.; Dos Remedios, C.; Stienen, G.J.; van der Velden, J. A piece of the human heart: Variance of protein phosphorylation in left ventricular samples from end-stage primary cardiomyopathy patients. J. Muscle Res. Cell Motil. 2009, 30, 299-302. [CrossRef] [PubMed]

61. Cai, Z.; Yan, L.J. Protein Oxidative Modifications: Beneficial Roles in Disease and Health. J. Biochem. Pharmacol. Res. 2013, 1, 15-26. [PubMed]

62. Wijnker, P.J.M.; Sequeira, V.; Kuster, D.W.D.; Velden, J.V. Hypertrophic Cardiomyopathy: A Vicious Cycle Triggered by Sarcomere Mutations and Secondary Disease Hits. Antioxid. Redox Signal. 2018. [CrossRef] [PubMed]

63. Predmore, J.M.; Wang, P.; Davis, F.; Bartolone, S.; Westfall, M.V.; Dyke, D.B.; Pagani, F.; Powell, S.R.; Day, S.M. Ubiquitin proteasome dysfunction in human hypertrophic and dilated cardiomyopathies. Circulation 2010, 121, 997-1004. [CrossRef] [PubMed]

64. Yin, Z.; Ren, J.; Guo, W. Sarcomeric protein isoform transitions in cardiac muscle: A journey to heart failure. Biochim. Biophys. Acta 2015, 1852, 47-52. [CrossRef] [PubMed] 
65. Hoskins, A.C.; Jacques, A.; Bardswell, S.C.; McKenna, W.J.; Tsang, V.; dos Remedios, C.G.; Ehler, E.; Adams, K.; Jalilzadeh, S.; Avkiran, M.; et al. Normal passive viscoelasticity but abnormal myofibrillar force generation in human hypertrophic cardiomyopathy. J. Mol. Cell. Cardiol. 2010, 49, 737-745. [CrossRef] [PubMed]

66. Marston, S.; Copeland, O.; Jacques, A.; Livesey, K.; Tsang, V.; McKenna, W.J.; Jalilzadeh, S.; Carballo, S.; Redwood, C.; Watkins, H. Evidence from human myectomy samples that MYBPC3 mutations cause hypertrophic cardiomyopathy through haploinsufficiency. Circ. Res. 2009, 105, 219-222. [CrossRef] [PubMed]

67. Sequeira, V.; Wijnker, P.J.; Nijenkamp, L.L.; Kuster, D.W.; Najafi, A.; Witjas-Paalberends, E.R.; Regan, J.A.; Boontje, N.; Ten Cate, F.J.; Germans, T.; et al. Perturbed length-dependent activation in human hypertrophic cardiomyopathy with missense sarcomeric gene mutations. Circ. Res. 2013, 112, 1491-1505. [CrossRef] [PubMed]

68. Van Dijk, S.J.; Paalberends, E.R.; Najafi, A.; Michels, M.; Sadayappan, S.; Carrier, L.; Boontje, N.M.; Kuster, D.W.; van Slegtenhorst, M.; Dooijes, D.; et al. Contractile dysfunction irrespective of the mutant protein in human hypertrophic cardiomyopathy with normal systolic function. Circ. Heart Fail. 2012, 5, 36-46. [CrossRef] [PubMed]

69. Belus, A.; Piroddi, N.; Scellini, B.; Tesi, C.; D’Amati, G.; Girolami, F.; Yacoub, M.; Cecchi, F.; Olivotto, I.; Poggesi, C. The familial hypertrophic cardiomyopathy-associated myosin mutation R403Q accelerates tension generation and relaxation of human cardiac myofibrils. J. Physiol. 2008, 586, 3639-3644. [CrossRef] [PubMed]

70. Piroddi, N.; Belus, A.; Scellini, B.; Tesi, C.; Giunti, G.; Cerbai, E.; Mugelli, A.; Poggesi, C. Tension generation and relaxation in single myofibrils from human atrial and ventricular myocardium. Pflugers Arch. 2007, 454, 63-73. [CrossRef] [PubMed]

71. Witjas-Paalberends, E.R.; Ferrara, C.; Scellini, B.; Piroddi, N.; Montag, J.; Tesi, C.; Stienen, G.J.; Michels, M.; Ho, C.Y.; Kraft, T.; et al. Faster cross-bridge detachment and increased tension cost in human hypertrophic cardiomyopathy with the R403Q MYH7 mutation. J. Physiol. 2014, 592, 3257-3272. [CrossRef] [PubMed]

72. Montag, J.; Kowalski, K.; Makul, M.; Ernstberger, P.; Radocaj, A.; Beck, J.; Becker, E.; Tripathi, S.; Keyser, B.; Muhlfeld, C.; et al. Burst-Like Transcription of Mutant and Wildtype MYH7-Alleles as Possible Origin of Cell-to-Cell Contractile Imbalance in Hypertrophic Cardiomyopathy. Front. Physiol. 2018, 9, 359. [CrossRef] [PubMed]

73. Kraft, T.; Witjas-Paalberends, E.R.; Boontje, N.M.; Tripathi, S.; Brandis, A.; Montag, J.; Hodgkinson, J.L.; Francino, A.; Navarro-Lopez, F.; Brenner, B.; et al. Familial hypertrophic cardiomyopathy: Functional effects of myosin mutation R723G in cardiomyocytes. J. Mol. Cell. Cardiol. 2013, 57, 13-22. [CrossRef] [PubMed]

74. Tripathi, S.; Schultz, I.; Becker, E.; Montag, J.; Borchert, B.; Francino, A.; Navarro-Lopez, F.; Perrot, A.; Ozcelik, C.; Osterziel, K.J.; et al. Unequal allelic expression of wild-type and mutated beta-myosin in familial hypertrophic cardiomyopathy. Basic Res. Cardiol. 2011, 106, 1041-1055. [CrossRef] [PubMed]

75. Montag, J.; Syring, M.; Rose, J.; Weber, A.L.; Ernstberger, P.; Mayer, A.K.; Becker, E.; Keyser, B.; Dos Remedios, C.; Perrot, A.; et al. Intrinsic MYH7 expression regulation contributes to tissue level allelic imbalance in hypertrophic cardiomyopathy. J. Muscle Res. Cell Motil. 2017, 38, 291-302. [CrossRef] [PubMed]

76. Vikhorev, P.G.; Smoktunowicz, N.; Munster, A.B.; Copeland, O.; Kostin, S.; Montgiraud, C.; Messer, A.E.; Toliat, M.R.; Li, A.; Dos Remedios, C.G.; et al. Abnormal contractility in human heart myofibrils from patients with dilated cardiomyopathy due to mutations in TTN and contractile protein genes. Sci. Rep. 2017, 7, 14829. [CrossRef] [PubMed]

77. Van Spaendonck-Zwarts, K.Y.; Posafalvi, A.; van den Berg, M.P.; Hilfiker-Kleiner, D.; Bollen, I.A.; Sliwa, K.; Alders, M.; Almomani, R.; van Langen, I.M.; van der Meer, P.; et al. Titin gene mutations are common in families with both peripartum cardiomyopathy and dilated cardiomyopathy. Eur. Heart J. 2014, 35, 2165-2173. [CrossRef] [PubMed]

78. Bollen, I.A.E.; Schuldt, M.; Harakalova, M.; Vink, A.; Asselbergs, F.W.; Pinto, J.R.; Kruger, M.; Kuster, D.W.D.; van der Velden, J. Genotype-specific pathogenic effects in human dilated cardiomyopathy. J. Physiol. 2017, 595, 4677-4693. [CrossRef] [PubMed]

79. Hoorntje, E.T.; Bollen, I.A.; Barge-Schaapveld, D.Q.; van Tienen, F.H.; Te Meerman, G.J.; Jansweijer, J.A.; van Essen, A.J.; Volders, P.G.; Constantinescu, A.A.; van den Akker, P.C.; et al. Lamin A/C-Related Cardiac Disease: Late Onset With a Variable and Mild Phenotype in a Large Cohort of Patients With the Lamin A/C p.(Arg331Gln) Founder Mutation. Circ. Cardiovasc. Genet. 2017, 10, e001631. [CrossRef] [PubMed] 
80. Beqqali, A.; Bollen, I.A.; Rasmussen, T.B.; van den Hoogenhof, M.M.; van Deutekom, H.W.; Schafer, S.; Haas, J.; Meder, B.; Sorensen, K.E.; van Oort, R.J.; et al. A mutation in the glutamate-rich region of RNA-binding motif protein 20 causes dilated cardiomyopathy through missplicing of titin and impaired Frank-Starling mechanism. Cardiovasc. Res. 2016, 112, 452-463. [CrossRef] [PubMed]

81. Dyer, E.C.; Jacques, A.M.; Hoskins, A.C.; Ward, D.G.; Gallon, C.E.; Messer, A.E.; Kaski, J.P.; Burch, M.; Kentish, J.C.; Marston, S.B. Functional analysis of a unique troponin c mutation, GLY159ASP, that causes familial dilated cardiomyopathy, studied in explanted heart muscle. Circ. Heart Fail. 2009, 2, 456-464. [CrossRef] [PubMed]

82. Vallins, W.J.; Brand, N.J.; Dabhade, N.; Butler-Browne, G.; Yacoub, M.H.; Barton, P.J. Molecular cloning of human cardiac troponin I using polymerase chain reaction. FEBS Lett. 1990, 270, 57-61. [CrossRef]

83. Chaturvedi, R.R.; Herron, T.; Simmons, R.; Shore, D.; Kumar, P.; Sethia, B.; Chua, F.; Vassiliadis, E.; Kentish, J.C. Passive stiffness of myocardium from congenital heart disease and implications for diastole. Circulation 2010, 121, 979-988. [CrossRef] [PubMed]

84. Van der Velden, J.; Papp, Z.; Zaremba, R.; Boontje, N.M.; de Jong, J.W.; Owen, V.J.; Burton, P.B.; Goldmann, P.; Jaquet, K.; Stienen, G.J. Increased $\mathrm{Ca}^{2+}$-sensitivity of the contractile apparatus in end-stage human heart failure results from altered phosphorylation of contractile proteins. Cardiovasc. Res. 2003, 57, $37-47$. [CrossRef]

85. Bollen, I.A.E.; Ehler, E.; Fleischanderl, K.; Bouwman, F.; Kempers, L.; Ricke-Hoch, M.; Hilfiker-Kleiner, D.; Dos Remedios, C.G.; Kruger, M.; Vink, A.; et al. Myofilament Remodeling and Function Is More Impaired in Peripartum Cardiomyopathy Compared with Dilated Cardiomyopathy and Ischemic Heart Disease. Am. J. Pathol. 2017, 187, 2645-2658. [CrossRef] [PubMed]

86. Kooij, V.; Saes, M.; Jaquet, K.; Zaremba, R.; Foster, D.B.; Murphy, A.M.; Dos Remedios, C.; van der Velden, J.; Stienen, G.J. Effect of troponin I Ser23/24 phosphorylation on Ca2+-sensitivity in human myocardium depends on the phosphorylation background. J. Mol. Cell. Cardiol. 2010, 48, 954-963. [CrossRef] [PubMed]

87. Kotter, S.; Gout, L.; Von Frieling-Salewsky, M.; Muller, A.E.; Helling, S.; Marcus, K.; Dos Remedios, C.; Linke, W.A.; Kruger, M. Differential changes in titin domain phosphorylation increase myofilament stiffness in failing human hearts. Cardiovasc. Res. 2013, 99, 648-656. [CrossRef] [PubMed]

88. Papp, Z.; van der Velden, J.; Borbely, A.; Edes, I.; Stienen, G.J.M. Altered myocardial force generation in end-stage human heart failure. ESC Heart Fail. 2014, 1, 160-165. [CrossRef] [PubMed]

89. Mamidi, R.; Li, J.; Gresham, K.S.; Verma, S.; Doh, C.Y.; Li, A.; Lal, S.; Dos Remedios, C.G.; Stelzer, J.E. Dose-Dependent Effects of the Myosin Activator Omecamtiv Mecarbil on Cross-Bridge Behavior and Force Generation in Failing Human Myocardium. Circ. Heart Fail. 2017, 10, e004257. [CrossRef] [PubMed]

90. Jeong, M.Y.; Lin, Y.H.; Wennersten, S.A.; Demos-Davies, K.M.; Cavasin, M.A.; Mahaffey, J.H.; Monzani, V.; Saripalli, C.; Mascagni, P.; Reece, T.B.; et al. Histone deacetylase activity governs diastolic dysfunction through a nongenomic mechanism. Sci. Transl. Med. 2018, 10. [CrossRef] [PubMed]

91. Yoshida, J.; Kawai, M.; Minai, K.; Ogawa, K.; Ogawa, T.; Yoshimura, M. Associations between Left Ventricular Cavity Size and Cardiac Function and Overload Determined by Natriuretic Peptide Levels and a Covariance Structure Analysis. Sci. Rep. 2017, 7, 2037. [CrossRef] [PubMed]

92. Reinstein, E.; Gutierrez-Fernandez, A.; Tzur, S.; Bormans, C.; Marcu, S.; Tayeb-Fligelman, E.; Vinkler, C.; Raas-Rothschild, A.; Irge, D.; Landau, M.; et al. Congenital dilated cardiomyopathy caused by biallelic mutations in Filamin C. Eur. J. Hum. Genet. 2016, 24, 1792-1796. [CrossRef] [PubMed]

93. Messer, A.E.; Gallon, C.E.; McKenna, W.J.; Dos Remedios, C.G.; Marston, S.B. The use of phosphate-affinity SDS-PAGE to measure the cardiac troponin I phosphorylation site distribution in human heart muscle. Proteom. Clin. Appl. 2009, 3, 1371-1382. [CrossRef] [PubMed]

94. Bodor, G.S.; Oakeley, A.E.; Allen, P.D.; Crimmins, D.L.; Ladenson, J.H.; Anderson, P.A. Troponin I phosphorylation in the normal and failing adult human heart. Circulation 1997, 96, 1495-1500. [CrossRef] [PubMed]

95. Song, W.; Dyer, E.; Stuckey, D.J.; Copeland, O.; Leung, M.C.; Bayliss, C.; Messer, A.; Wilkinson, R.; Tremoleda, J.L.; Schneider, M.D.; et al. Molecular mechanism of the E99K mutation in cardiac actin (ACTC Gene) that causes apical hypertrophy in man and mouse. J. Biol. Chem. 2011, 286, 27582-27593. [CrossRef] [PubMed] 
96. Hamdani, N.; Kooij, V.; van Dijk, S.; Merkus, D.; Paulus, W.J.; Remedios, C.D.; Duncker, D.J.; Stienen, G.J.; van der Velden, J. Sarcomeric dysfunction in heart failure. Cardiovasc. Res. 2008, 77, 649-658. [CrossRef] [PubMed]

97. Copeland, O.; Sadayappan, S.; Messer, A.E.; Steinen, G.J.; van der Velden, J.; Marston, S.B. Analysis of cardiac myosin binding protein-C phosphorylation in human heart muscle. J. Mol. Cell. Cardiol. 2010, 49, 1003-1011. [CrossRef] [PubMed]

98. Jacques, A.M.; Briceno, N.; Messer, A.E.; Gallon, C.E.; Jalilzadeh, S.; Garcia, E.; Kikonda-Kanda, G.; Goddard, J.; Harding, S.E.; Watkins, H.; et al. The molecular phenotype of human cardiac myosin associated with hypertrophic obstructive cardiomyopathy. Cardiovasc. Res. 2008, 79, 481-491. [CrossRef] [PubMed]

99. Papadaki, M.; Vikhorev, P.G.; Marston, S.B.; Messer, A.E. Uncoupling of myofilament $\mathrm{Ca}^{2+}$ sensitivity from troponin I phosphorylation by mutations can be reversed by epigallocatechin-3-gallate. Cardiovasc. Res. 2015, 108, 99-110. [CrossRef] [PubMed]

100. Messer, A.E.; Bayliss, C.R.; El-Mezgueldi, M.; Redwood, C.S.; Ward, D.G.; Leung, M.C.; Papadaki, M.; Dos Remedios, C.; Marston, S.B. Mutations in troponin T associated with Hypertrophic Cardiomyopathy increase $\mathrm{Ca}(2+)$-sensitivity and suppress the modulation of $\mathrm{Ca}(2+)$-sensitivity by troponin I phosphorylation. Arch. Biochem. Biophys. 2016, 601, 113-120. [CrossRef] [PubMed]

101. Messer, A.E.; Chan, J.; Daley, A.; Copeland, O.; Marston, S.B.; Connolly, D.J. Investigations into the Sarcomeric Protein and $\mathrm{Ca}(2+)$-Regulation Abnormalities Underlying Hypertrophic Cardiomyopathy in Cats (Felix catus). Front. Physiol. 2017, 8, 348. [CrossRef] [PubMed]

102. Bayliss, C.R.; Jacques, A.M.; Leung, M.C.; Ward, D.G.; Redwood, C.S.; Gallon, C.E.; Copeland, O.; McKenna, W.J.; Dos Remedios, C.; Marston, S.B.; et al. Myofibrillar Ca(2+) sensitivity is uncoupled from troponin I phosphorylation in hypertrophic obstructive cardiomyopathy due to abnormal troponin $\mathrm{T}$. Cardiovasc. Res. 2013, 97, 500-508. [CrossRef] [PubMed]

103. Vikhorev, P.G.; Song, W.; Wilkinson, R.; Copeland, O.; Messer, A.E.; Ferenczi, M.A.; Marston, S.B. The dilated cardiomyopathy-causing mutation ACTC E361G in cardiac muscle myofibrils specifically abolishes modulation of $\mathrm{Ca}(2+)$ regulation by phosphorylation of troponin I. Biophys. J. 2014, 107, 2369-2380. [CrossRef] [PubMed]

104. Biesiadecki, B.J.; Kobayashi, T.; Walker, J.S.; Solaro, R.J.; de Tombe, P.P. The troponin C G159D mutation blunts myofilament desensitization induced by troponin I Ser23/24 phosphorylation. Circ. Res. 2007, 100, 1486-1493. [CrossRef] [PubMed]

105. Messer, A.E.; Marston, S.B. Investigating the role of uncoupling of troponin I phosphorylation from changes in myofibrillar $\mathrm{Ca}(2+)$-sensitivity in the pathogenesis of cardiomyopathy. Front. Physiol. 2014, 5, 315. [CrossRef] [PubMed]

106. Edes, I.F.; Czuriga, D.; Csanyi, G.; Chlopicki, S.; Recchia, F.A.; Borbely, A.; Galajda, Z.; Edes, I.; van der Velden, J.; Stienen, G.J.; et al. Rate of tension redevelopment is not modulated by sarcomere length in permeabilized human, murine, and porcine cardiomyocytes. Am. J. Physiol. Regul. Integr. Comp. Physiol. 2007, 293, R20-R29. [CrossRef] [PubMed]

107. McNamara, J.W.; Li, A.; Lal, S.; Bos, J.M.; Harris, S.P.; van der Velden, J.; Ackerman, M.J.; Cooke, R.; Dos Remedios, C.G. MYBPC3 mutations are associated with a reduced super-relaxed state in patients with hypertrophic cardiomyopathy. PLoS ONE 2017, 12, e0180064. [CrossRef] [PubMed]

108. Van Dijk, S.J.; Dooijes, D.; dos Remedios, C.; Michels, M.; Lamers, J.M.; Winegrad, S.; Schlossarek, S.; Carrier, L.; ten Cate, F.J.; Stienen, G.J.; et al. Cardiac myosin-binding protein C mutations and hypertrophic cardiomyopathy: Haploinsufficiency, deranged phosphorylation, and cardiomyocyte dysfunction. Circulation 2009, 119, 1473-1483. [CrossRef] [PubMed]

109. Rottbauer, W.; Gautel, M.; Zehelein, J.; Labeit, S.; Franz, W.M.; Fischer, C.; Vollrath, B.; Mall, G.; Dietz, R.; Kubler, W.; et al. Novel splice donor site mutation in the cardiac myosin-binding protein-C gene in familial hypertrophic cardiomyopathy. Characterization Of cardiac transcript and protein. J. Clin. Investig. 1997, 100, 475-482. [CrossRef] [PubMed]

110. Gilda, J.E.; Gomes, A.V. Proteasome dysfunction in cardiomyopathies. J. Physiol. 2017, 595, 4051-4071. [CrossRef] [PubMed]

111. Makarenko, I.; Opitz, C.A.; Leake, M.C.; Neagoe, C.; Kulke, M.; Gwathmey, J.K.; del Monte, F.; Hajjar, R.J.; Linke, W.A. Passive stiffness changes caused by upregulation of compliant titin isoforms in human dilated cardiomyopathy hearts. Circ. Res. 2004, 95, 708-716. [CrossRef] [PubMed] 
112. Nagueh, S.F.; Shah, G.; Wu, Y.; Torre-Amione, G.; King, N.M.; Lahmers, S.; Witt, C.C.; Becker, K.; Labeit, S.; Granzier, H.L. Altered titin expression, myocardial stiffness, and left ventricular function in patients with dilated cardiomyopathy. Circulation 2004, 110, 155-162. [CrossRef] [PubMed]

113. Roberts, A.M.; Ware, J.S.; Herman, D.S.; Schafer, S.; Baksi, J.; Bick, A.G.; Buchan, R.J.; Walsh, R.; John, S.; Wilkinson, S.; et al. Integrated allelic, transcriptional, and phenomic dissection of the cardiac effects of titin truncations in health and disease. Sci. Transl. Med. 2015, 7, 270ra6. [CrossRef] [PubMed]

114. Rice, J.J.; Winslow, R.L.; Hunter, W.C. Comparison of putative cooperative mechanisms in cardiac muscle: Length dependence and dynamic responses. Am. J. Physiol. 1999, 276, H1734-H1754. [CrossRef] [PubMed]

115. Beuckelmann, D.J.; Nabauer, M.; Erdmann, E. Intracellular calcium handling in isolated ventricular myocytes from patients with terminal heart failure. Circulation 1992, 85, 1046-1055. [CrossRef] [PubMed]

116. Gwathmey, J.K.; Slawsky, M.T.; Hajjar, R.J.; Briggs, G.M.; Morgan, J.P. Role of intracellular calcium handling in force-interval relationships of human ventricular myocardium. J. Clin. Investig. 1990, 85, 1599-1613. [CrossRef] [PubMed]

117. Bayer, J.D.; Narayan, S.M.; Lalani, G.G.; Trayanova, N.A. Rate-dependent action potential alternans in human heart failure implicates abnormal intracellular calcium handling. Heart Rhythm 2010, 7, 1093-1101. [CrossRef] [PubMed]

118. Dewey, S.; Xu, Q.; Gomes, A. Static and dynamic properties of the HCM myocardium. J. Mol. Cell. Cardiol. 2010, 49, 715-718. [CrossRef] [PubMed]

119. Poggesi, C.; Ho, C.Y. Muscle dysfunction in hypertrophic cardiomyopathy: What is needed to move to translation? J. Muscle Res. Cell. Motil. 2014, 35, 37-45. [CrossRef] [PubMed]

(C) 2018 by the authors. Licensee MDPI, Basel, Switzerland. This article is an open access article distributed under the terms and conditions of the Creative Commons Attribution (CC BY) license (http:/ / creativecommons.org/licenses/by/4.0/). 